\title{
THE COOLING INTENSITY DEPENDENT ON LANDSCAPE COMPLEXITY OF GREEN INFRASTRUCTURE IN THE METROPOLITAN AREA
}

\author{
Yuncai WANG ${ }^{1} 2^{*}$, Junda $\mathrm{HUANG}^{2}$, Chundi $\mathrm{CHEN}^{1}$, Jiake $\mathrm{SHEN}^{2}$, Shuo SHENG ${ }^{2}$ \\ ${ }^{1}$ Center of Ecological Planning and Environment Effects Research, Key Laboratory of Ecology and \\ Energy-saving Study of Dense Habitat, Ministry of Education, Shanghai, China \\ ${ }^{2}$ Department of Landscape Architecture, College of Architecture and Urban Planning, \\ Tongji University, Shanghai, China
}

Received 26 August 2020; accepted 06 May 2021

\footnotetext{
Highlights

- The study explores relationships between landscape complexity and cooling effect.

- GI provides a stronger cooling effect in the densely built-up area than green belt.

$>$ GI with a simple form and aggregated configuration had a better cooling intensity.

The TVoE of forest and grass are different in the two regions.
}

\begin{abstract}
The cooling effect of green infrastructure (GI) is becoming a hot topic on mitigating the urban heat island (UHI) effect. Alterations to the green space are a viable solution for reducing land surface temperature (LST), yet few studies provide specific guidance for landscape planning adapted to the different regions. This paper proposed and defined the landscape complexity and the threshold value of cooling effect (TVoE). Results find that: (1) GI provides a better cooling effect in the densely built-up area than the green belt; (2) GI with a simple form, aggregated configuration, and low patch density had a better cooling intensity; (3) In the densely built-up area, TVoE of the forest area is 4.5 ha, while in the green belt, TVoE of the forest and grassland area is 9 ha and 2.25 ha. These conclusions will help the planners to reduce LST effectively, and employ environmentally sustainable planning.
\end{abstract}

Keywords: urban cooling island, cooling effect, landscape topography, landscape composition, spatial configuration, the densely built-up area, the green belt, environmental sustainability.

\section{Introduction}

As the population shifts from rural to urban areas, the proportion of the urban population is gradually increasing. It is estimated that by 2050 , approximately $64 \%$ of developing countries and $86 \%$ of developed countries will achieve urbanization, most of which will appear in Africa and Asia (John et al., 2014; United Nations [UN], 2014). Urbanization transforms natural habitats into a manmade environment by changing the flow of material and energy, which inevitably affects the ecosystem in various ways. One of the most well-known phenomena should belong to the urban heat island (UHI) (Voogt \& Oke, 2003), which refers to the densely built-up area has a higher land surface temperature (LST) than the suburbs. This phenomenon is mainly caused by the conversion of surface thermal properties and the heat generated by energy consumption (Li \& Zhao, 2012; Solecki et al., 2005). Given the fact that the impacts and hazards of UHI have been widespread around the world, such as accelerating energy consumption (Santamouris et al., 2015; Zhou et al., 2019a), reducing biodiversity (Ceplova et al., 2017), increasing the frequency of extreme climate events (Zhao et al., 2019), and affecting the health and life comfort of urban residents (Fu et al., 2019; Mallen et al., 2019; Wang et al., 2019a). Moreover, the enhancement of the global greenhouse effect has also exacerbated the impact of UHI on human settlements. Therefore, for the environmental sustainability of global urbanization and

${ }^{*}$ Corresponding author. E-mail: wyc1967@tongji.edu.cn 
human welfare, a deeper analysis of mitigating the UHI effect is being an emergency task than ever before.

Green infrastructure (GI) as a complex system is influenced by both the natural environment and human behavior (Berardi et al., 2014; Wang et al., 2018; Weng et al., 2008). It mainly contains tree canopy, green open spaces, green roofs, and vertical greenery systems (Rouse \& Bunster-Ossa, 2013). This sort of land cover has a significant cooling effect on regional temperatures, which has been confirmed by numerous studies (Bartesaghi Koc et al., 2018; Chui et al., 2018; Demuzere et al., 2014). For example, in London, the mean temperature reduction of GI was $1.1^{\circ} \mathrm{C}$, with a maximum of $4{ }^{\circ} \mathrm{C}$ cooling observed on some nights (Doick et al., 2014). In Copenhagen, bluegreen space provides a higher cooling-effect in summer, and the mean cooling extent and intensity are $150 \mathrm{~m}$ and $2.47^{\circ} \mathrm{C}$ (Yang et al., 2020). At the same time, studies have found that more complex green infrastructure (i.e., more semi-natural or natural land cover) can accommodate more rich and diverse biomes, providing better ecosystem services to the city (Koc et al., 2017). In particular, the cooling effect was also enhanced as an important component of ecosystem services.

In the existing literature, Fivos Papadimitriou reviews the different objects of complexity research, summarizes and classifies landscape complexity into three main categories: structural landscape complexity, functional/hierarchical landscape complexity, and qualitative landscape complexity (Papadimitriou, 2010). Among them, structural landscape complexity is calculated in a raster or vector map as quantifying the cooling effect of green space, cell by cell, pixel by pixel. It characterizes the spatial feature complexity of all landscapes and serves as the theoretical basis for the research on the cooling effect of GI complexity in this study.

Although diversity, heterogeneity, and connectivity are the key features of complex systems, the concept of complexity can accept different approaches and definitions, and they are not unique (Ode et al., 2010). Therefore, in current cooling studies of GI complexity, there is no fixed system of quantification of complexity, and the indicators of distribution, morphology, and area of green space are usually chosen, such as the urban cooling island (UCI) effect is affected by forest vegetation area, spatial distribution, cooling island composition, and surrounding thermal environment in a large metropolitan area (Kong et al., 2014b). The study based on the neighborhood environments in Austin concluded that the larger and betterconnected landscape spatial pattern is positively correlated with the lower LST, while the isolated landscape pattern is negatively (Kim et al., 2016). And Peng et al. (2016) reported that when GI coverage exceeded $70 \%\left(25 \mathrm{~km}^{2}\right)$ of the total land area, the cooling effect of this landscape type was relatively obvious, which meant landscape composition affected the LST more than did spatial configuration (Peng et al., 2016).

Until now, most studies have been analyzed using a combination of known landscape-ecology indices, which leaves the disciplines of landscape ecology, geography, and urban planning still lacking interconnections at the landscape level. Meanwhile, studies on the relationship between the cooling effect and complexity of GI have focused on the size, form, and spatial structure of GI, as well as comparing the differences in cooling effects across time series. Therefore, there is a shortage of forming a framework of indicators based on structural landscape complexity, containing multiple spatial dimensions, and detailed quantitative analysis of cooling effects for GI types.

Furthermore, there are still some research gaps in the quantification of the cooling effect. In terms of methods to quantify the cooling effect, existing studies on the calculation of the GI cooling effect mainly take the interpolation of the regional average LST and the study cell average LST as a reference (Zhang et al., 2017c; Zhou et al., 2019a). But based on the object of the cooling effect of GI, few studies investigate the GI located in the space with low urban density surrounding the densely built-up area. The cooling effect provided by these green spaces, called the "green belt", is also one part of the important ecosystem service, which has different space and cooling features from the densely built-up area (Hernandez-Moreno \& Reyes-Paecke, 2018; Imran et al., 2019). Thus, consolidating multiple regions as a whole zone will limit the city planners to do the right decisions from a comprehensive perspective, and restricts the ability to make specific suggestions for different regions of the city (Ngulani \& Shackleton, 2020; Rubiano, 2019; $\mathrm{Wu}$ et al., 2019). And the specific impact degree and cooling intensity of GI planning in different regions on the urban thermal environment are well unknown, such as which are the key factors to provide cooling, considering the respective spatial characteristics of GI in the densely built-up area and its surrounding area? Is there an optimal threshold of landscape complexity index for cooling? Which GI types being parts of the urban ecosystem have the strongest cooling intensity in terms of landscape complexity index? What is the difference in the cooling threshold between the regions?

To answer these questions and improve the ability of urban planning to achieve the goals that build an integrated temperature regulation mechanism at the regional scale and study the cold island effect of GI in the built-up area and its surrounding spaces, this study calculates and discusses the quantitative roles between GI and its cooling intensity in different regions by building a landscape complexity index framework in terms of the mature indicators. The metropolitan area of Taiyuan with arid climate in China was taken as the study area, and was divided into two regions, the densely built-up area with urban buildings and impervious surfaces as the main land use types, and the green belt around the densely built-up area with forests, grasslands and villages. Six indicators and LST were used to calculate the cooling effect of UCI between the two regions. The main aims are to (1) quantify the cooling intensity of GI in 
the two regions, and compare the difference of LST with the trend of two directions between them; (2) identify the optimal landscape complexity, according to the cooling intensity and efficiency of UCI; (3) determine and verify the specific cooling threshold regarding the landscape complexity index; (4) propose suggestions for sustainable development of GI planning in arid cities.

\section{Materials and methods}

\subsection{Study area and data preprocessing}

Taiyuan is the capital of Shanxi Province, located in central China $\left(111^{\circ} 30^{\prime}-113^{\circ} 09^{\prime} \mathrm{E}, 37^{\circ} 27^{\prime}-38^{\circ} 25^{\prime} \mathrm{N}\right)$, hosting 4.42 million inhabitants in 2019. The city is located in the eastern part of the Loess Plateau, with a typical continental monsoon climate characteristic of the northern temperate zone (Estes et al., 2016). The humid air is blocked by the mountains surrounding the cities, causing low precipitation, hot and dry environmental characteristics, which is similar to most highly urbanized cities at the same latitude zone (Esau et al., 2019; Geletič et al., 2019). Its average annual rainfall is $456 \mathrm{~mm}$, mainly in July and August. Recently, the rapid development of heavy industries such as coal mining and metal smelting has led to a significant increase in extreme weather events, especially in the periphery of the built-up area (Zhao et al., 2021). In addition, the limited land resources of the river valley plain lead to the expansion of construction land into the surroundings, which deteriorates the health of the regional environment, and threatens the stability of the entire ecological pattern. Taiyuan is becoming one of the hottest cities in central China. For example, in July 2017, the city broke its highest temperature record in a century, exceeding $40.8^{\circ} \mathrm{C}$. And in 2018 , the maximum temperature exceeded $35{ }^{\circ} \mathrm{C}$ lasted twenty days. Therefore, the government has planned the Taiyuan metropolitan area including the built-up area and its surrounding areas to rationalize the development of the city and improve the cooling effect provided by the GI.

This study takes Taiyuan metropolitan area as the study area, covering $1,460 \mathrm{~km}^{2}$, with a population of 2.75 million and an urbanization rate of $84.7 \%$. By the end of 2019, the city's GDP had reached 55.48 billion US dollars, and GDP per capita was 13,147 US dollars, with a steady annual growth rate of $6.6 \%$ (Bureau of Statistics, Taiyuan, China). However, the densely built-up area, located in the Fenhe River Valley Plain, covers $618 \mathrm{~km}^{2}$ where has a high population density of 3,750 persons/ $\mathrm{km}^{2}$. Although the land in the densely built-up area is strongly influenced by human activities, Taiyuan, as a national garden city in China, has good protection of native indigenous vegetation which are mainly evergreen coniferous species and deciduous broadleaf species. Inversely, the annular space surrounding the densely builtup area has a low population density of 522 persons $/ \mathrm{km}^{2}$, where human activities mainly revolve around point-like villages without large-scale construction. The plants in the green belt are mainly planted forests, with evergreen coniferous species and deciduous broad-leaved species predominating. The water bodies are dominated by a reservoir and upper reaches of the tributaries. This region is an important environmental protection land, providing major ecosystem services for the densely built-up area. Thus, based on the geography, population distribution, and existing physical space such as roads, buildings, and urban development boundaries within the Taiyuan metropolitan area this whole area is divided into two regions: the densely built-up area and its surrounding green belt (Figure 1).

The data used in this study was the land use classification dataset of the Taiyuan metropolitan area, Landsat 8 satellite imagery, and HD Google images. The 2019 landuse dataset came from the third national land survey in China, a resolution of $30 \mathrm{~m}$. The operational land imager and thermal infrared data of Landsat 8 were acquired from the United States Geological Survey website, with a resolution of $30 \mathrm{~m}$ and $100 \mathrm{~m}$ (http://earthexplorer.usgs.gov/). The image was collected on August 15, 2019, capturing at GMT 03:06 AM. There were several reasons for choosing this time. On the one hand, it was a time when Taiyuan had just finished its rainy season, with fewer clouds and trees possessing abundant foliage. On the other hand, by comparing the average near-ground temperature in recent years, August could satisfy the premise of fewer clouds and no sudden drop in temperature, which was suitable to study the cooling effect of GI. HD Google images were downloaded from Google Earth Pro software.

The Landsat Ecosystem Disturbance Adaptive Processing System was used to convert raw remote sensing data to surface reflectance (Masek et al., 2006). Normalization Different Vegetation Index (NDVI) and Modified Normalization Different Water Index (MNDWI) was calculated and stacked into the surface reflectance image of 2019. The Support Vector Machines (SVM) technique was used to identify land cover (Chen \& Yu, 2017). Land cover was classified into five categories: (1) farmland (annual arable land, rotation land), (2) waterbody, (3) forest (including shrubland), (4) grassland, (5) urban land, road, bare land, and other impervious surfaces analyzed as the background layer. In this study, GI consists of farmland, waterbody, forest, and grassland (Figure 2b). Then, 300 random points for each category were generated within the overlapping area of Google Earth and the Landsat 8 image. 1,500 points were used to train the classifier for the SVM based on the surface reflectance image. At last, to verify the accuracy of the land classification, the Google Earth image of Taiyuan was used to verify the classification results of the SVM (Congalton, 1991). Another 300 random points for each category were selected to construct the Region of Interest (ROI), and the results of the SVM were calibrated by confusion matrix (Table 1). The accuracy verification result is about $89.3 \%$ (Table 2). The above steps were implemented in ENVI 5.3, mainly using the Support Vector Machine Classification and Generate Random Sample Using Ground Truth ROIs tools. 

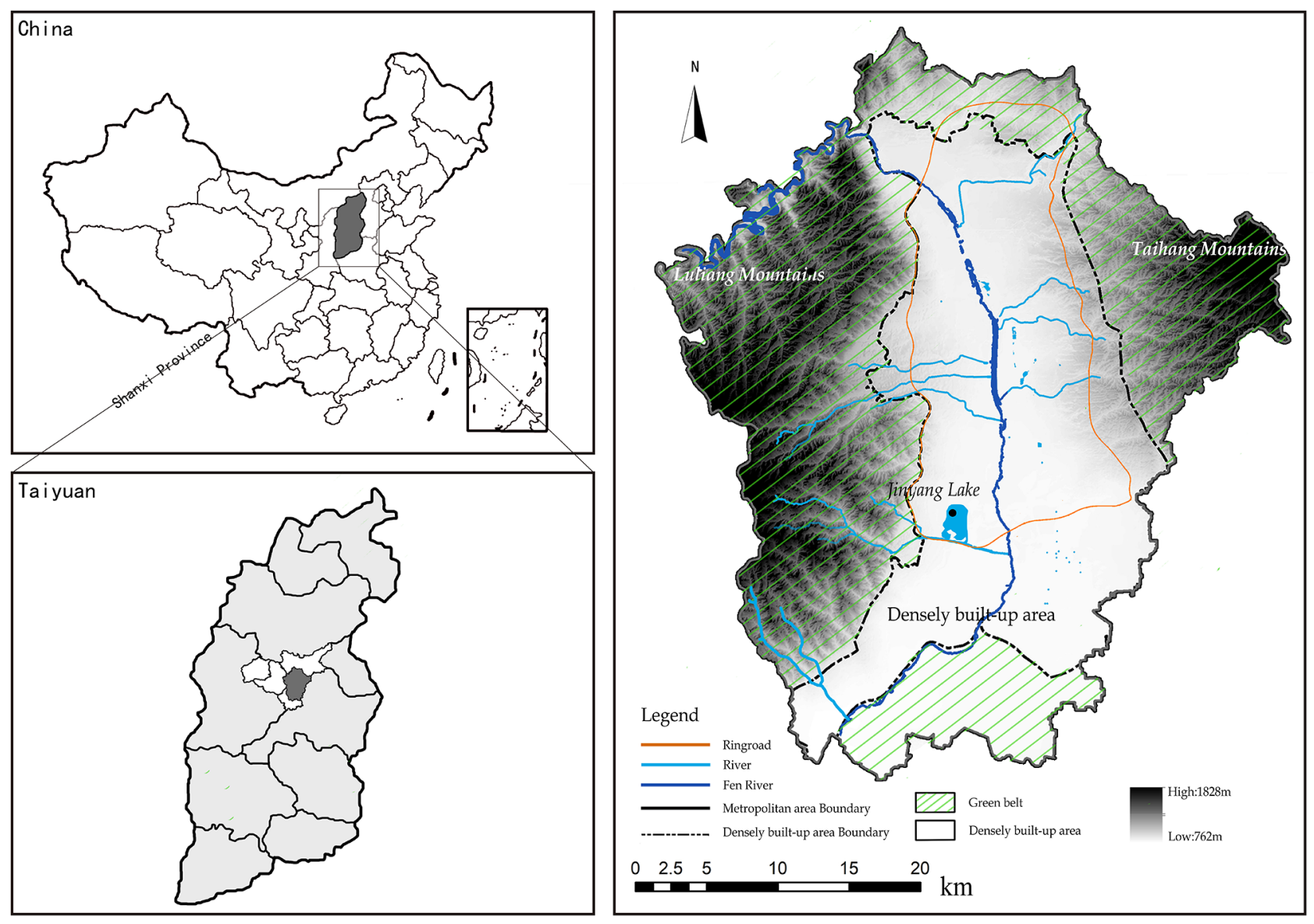

Figure 1. Study area

Table 1. The error matrix for land use classification

\begin{tabular}{|l|c|c|c|c|c|c|}
\hline Land use & $\begin{array}{c}\text { Farm- } \\
\text { land }\end{array}$ & $\begin{array}{c}\text { Water- } \\
\text { body }\end{array}$ & $\begin{array}{c}\text { Fo- } \\
\text { rest }\end{array}$ & $\begin{array}{c}\text { Grass- } \\
\text { land }\end{array}$ & $\begin{array}{c}\text { Urban } \\
\text { land, etc. }\end{array}$ & $\begin{array}{c}\text { To- } \\
\text { tal }\end{array}$ \\
\hline Farmland & 292 & 0 & 0 & 5 & 3 & 300 \\
\hline Waterbody & 4 & 283 & 5 & 0 & 8 & 300 \\
\hline Forest & 10 & 2 & 259 & 17 & 12 & 300 \\
\hline Grassland & 14 & 0 & 12 & 267 & 7 & 300 \\
\hline $\begin{array}{l}\text { Urban land, } \\
\text { etc. }\end{array}$ & 24 & 0 & 2 & 3 & 271 & 300 \\
\hline Total & 344 & 285 & 278 & 297 & 301 & 1500 \\
\hline
\end{tabular}

Table 2. The result of Kappa statistics

\begin{tabular}{|c|c|c|c|c|c|}
\hline \multicolumn{2}{|c|}{ Types } & \multirow{2}{*}{$\begin{array}{l}\text { Value } \\
0.893\end{array}$} & \multirow{2}{*}{$\begin{array}{c}\begin{array}{c}\text { Progressive } \\
\text { Standard } \\
\text { Error }\end{array} \\
0.009\end{array}$} & \multirow{2}{*}{$\begin{array}{c}\begin{array}{c}\text { Approx. } \\
\text { T b }\end{array} \\
69.249\end{array}$} & \multirow{2}{*}{$\begin{array}{c}\begin{array}{c}\text { Approx. } \\
\text { Signifi- } \\
\text { cance }\end{array} \\
0.000\end{array}$} \\
\hline Detection & Kappa & & & & \\
\hline $\begin{array}{l}\text { Number of } \\
\text { observatio }\end{array}$ & valid & 1500 & - & - & - \\
\hline
\end{tabular}

Notes: a. Unused null hypothesis. b. Asymptotic standard errors with the null hypothesis being used.

\subsection{Land surface temperature retrieval}

An atmospheric correction method was used to invert the LST of Taiyuan (Liu et al., 2017). First, ENVI 5.3 was used to do radiometric calibration and correction for atmospheric effects on data (Chander et al., 2009; Czapla-Myers et al., 2015). The Radiative Transfer Equation of the thermal infrared radiance value $L_{\lambda}$ was:

$$
\begin{aligned}
& L_{\lambda}=\left[\varepsilon B\left(T_{S}\right)+(1-\varepsilon)\right] \tau+L \uparrow_{\lambda} ; \\
& B\left(T_{S}\right)=\frac{\left[L_{\lambda}-L \downarrow_{\lambda}-\tau(1-\varepsilon) L \downarrow_{\lambda}\right]}{\tau \varepsilon},
\end{aligned}
$$

where $\varepsilon$ is the surface emissivity, $B\left(T_{S}\right)$ means the heat radiation brightness of black body, $T_{S}$ means true LST value (K), $L \uparrow_{\lambda}$ means effective bandpass upwelling radiance, $L \downarrow_{\lambda}$ means effective bandpass downwelling radiance, while $\tau$ means band average atmospheric transmission.

$T_{S}$ was converted by Planck's law function as followed:

$$
T_{S}=\frac{K_{2}}{\ln \left(\frac{K_{1}}{B\left(T_{S}\right)}+1\right)},
$$


a)

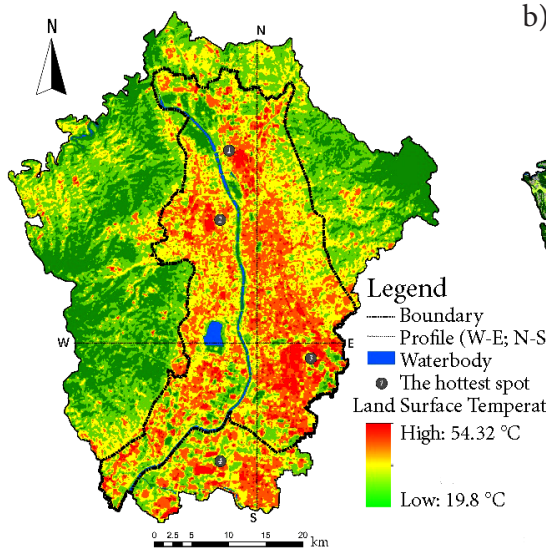

b)

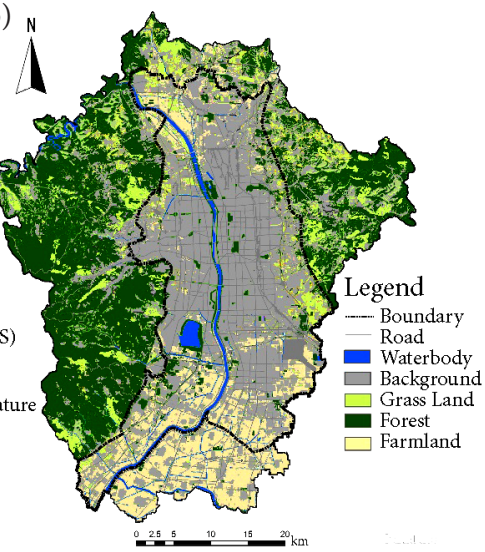

Figure 2. (a) The spatial distribution of LST in Taiyuan 2019; (b) The distribution of landscape elements in Taiyuan, 2019

where $K_{1}$ and $K_{2}$ are the calibration value. When it is Landsat8 TIRS Band $10, K_{1}=774.89 \mathrm{~W} /\left(\mathrm{m}^{2} \cdot \mathrm{sr} \cdot \mu \mathrm{m}\right)$, $K_{2}=1321.08 \mathrm{~K} . \varepsilon$ is calculated by the NDVI threshold method (Julien \& Sobrino, 2010; Sobrino et al., 2004).

Therefore, to calculate true LST data, two parameters should be obtained: the atmospheric profile parameters and surface emissivity $(\varepsilon)$. The former was obtained through NASA's official website (http://atmcorr.gsfc.nasa.gov/), inputting the acquisition time of landsat8 data, the latitude, and the longitude of the regional center. This study used $112.53 \mathrm{E}, 37.87 \mathrm{~N}$, and got $L \uparrow_{\lambda}=1.37 \mathrm{~W} /\left(\mathrm{m}^{2} \cdot \mathrm{sr} \cdot \mu \mathrm{m}\right)$, $L \downarrow_{\lambda}=2.37 \mathrm{~W} / \mathrm{m}^{2} \cdot \mathrm{sr} \cdot \mu \mathrm{m}$ and $\tau=0.83$. The latter was obtained by the NDVI threshold method through vegetation coverage and NDVI (Carlson \& Ripley, 1997; Zhang et al., 2017a). Finally, the true surface temperature was calculated by converting the blackbody radiation brightness by Planck's law function (Figure 2a).

\subsection{Indicators of landscape complexity}

Six relevant indicators were selected from three dimensions of landscape topography, landscape composition, and spatial configuration to characterize the landscape complexity of GI. They were Terrain niche index (TNI), Simpson's diversity index (SIDI), Percent of landscape (PLAND), Patch density (PD), Landscape division index (DIVISION), and Fractal dimension index (FDI) (Table 3). PLAND, SIDI, DIVISION, and PD were calculated by the moving window method in Fragstats4.2; TNI and FDI were calculated by the ArcGIS grid calculator.

\subsubsection{Landscape complexity indicators of landscape topography}

The traditional geographic analysis mainly studied single or multiple terrain variables through the Digital

Table 3. The calculation of landscape complexity indicators

\begin{tabular}{|c|c|c|c|c|}
\hline Dimension & $\begin{array}{c}\text { Index } \\
\text { (abbreviation) }\end{array}$ & Level & Description (unit) & Equation \\
\hline $\begin{array}{l}\text { Landscape } \\
\text { topography }\end{array}$ & $\begin{array}{l}\text { Terrain niche } \\
\text { index (TNI) }\end{array}$ & Landscape & $\begin{array}{l}E \text { and } S \text { are the elevations and slope values of } \\
\text { any point in the area. } \bar{E} \text { and } \bar{S} \text { are the average } \\
\text { elevation and average slope value of the area } \\
\text { where the point is located. (none) }\end{array}$ & $\mathrm{TNI}=\log \left[\left(\frac{E}{\bar{E}}+1\right) \cdot\left(\frac{S}{\bar{S}}+1\right)\right]$ \\
\hline \multirow{2}{*}{$\begin{array}{l}\text { Landscape } \\
\text { composition }\end{array}$} & $\begin{array}{l}\text { Simpson's } \\
\text { diversity index } \\
\text { (SIDI) }\end{array}$ & Landscape & $\begin{array}{l}P_{i} \text { is the proportion of landscape occupied by } \\
\text { patch type (class) } i, \mathrm{~m} \text { is the number of patch type } \\
\text { (class). (none) }\end{array}$ & $\mathrm{SIDI}=1-\sum_{i=1}^{m} P_{i}^{2}$ \\
\hline & $\begin{array}{l}\text { Percent of } \\
\text { landscape } \\
\text { (PLAND) }\end{array}$ & Class & $\begin{array}{l}P_{i} \text { is the proportion of landscape occupied by } \\
\text { patch type (class) } i . a_{i j} \text { is the area }\left(\mathrm{m}^{2}\right) \text { of patch } i j . \\
A \text { is the total landscape area }\left(\mathrm{m}^{2}\right) .(\text { Percent) }\end{array}$ & $\operatorname{PLAND}=P_{i}=\frac{\sum_{i=1}^{n} a_{i j}}{A}(100)$ \\
\hline \multirow{3}{*}{$\begin{array}{l}\text { Spatial } \\
\text { configuration }\end{array}$} & $\begin{array}{l}\text { Patch density } \\
\text { (PD) }\end{array}$ & $\begin{array}{l}\text { Landscape/ } \\
\text { Class }\end{array}$ & $\begin{array}{l}\text { A is the total landscape area }\left(\mathrm{m}^{2}\right) \cdot n_{i} \text { is the total } \\
\text { area of landscape element } i .\left(\mathrm{n} / \mathrm{km}^{2}\right)\end{array}$ & $\mathrm{PD}=\frac{n_{i}}{\mathrm{~A}}\left(\begin{array}{lll}10 & 000\end{array}\right)$ \\
\hline & $\begin{array}{l}\text { Fractal } \\
\text { dimension } \\
\text { index }(\mathrm{FDI})\end{array}$ & $\begin{array}{l}\text { Landscape/ } \\
\text { Class }\end{array}$ & $\begin{array}{l}A(r) \text { is the size of a certain patch, } P(r) \text { is the size } \\
\text { of a certain patch's perimeter, } D \text { is the fractal } \\
\text { dimension. (none) }\end{array}$ & $\ln A(r)=\frac{2}{D} \ln P(r)$ \\
\hline & $\begin{array}{l}\text { Landscape } \\
\text { division index } \\
\text { (DIVISION) }\end{array}$ & $\begin{array}{l}\text { Landscape/ } \\
\text { Class }\end{array}$ & $\begin{array}{l}a_{i j} \text { is the area }\left(\mathrm{m}^{2}\right) \text { of patch } \mathrm{ij} . A \text { is the total } \\
\text { landscape area }\left(\mathrm{m}^{2}\right) \text {. (proportion) }\end{array}$ & DIVISION $=\left[1-\sum_{i=1}^{n}\left(\frac{a_{i j}}{A}\right)^{2}\right]$ \\
\hline
\end{tabular}


Elevation Model (Chian \& Wilkinson, 2015; Noori et al., 2019). However, at the city scale, the interior and exterior may have different topography. To explore the impact of different topography, TNI is a comprehensive indicator of slope and elevation, which can reflect the different biogeographical environments where GI is located (Gong et al., 2017). The high elevation and large slope of the region indicate a high value of TNI; otherwise, it means low. While the area with low elevation and large slope, or high elevation and small slope, the TNI value tends to be average. In other words, the indicator summarizing the characteristics of geomorphology can make it easier to discover and understand the relationship with LST.

\subsubsection{Landscape complexity indicators of landscape composition}

Landscape composition includes PLAND and SIDI. As one of the commonly used indicators in ecological researches (Bokaie et al., 2016), PLAND is an important factor for studying the correlation between land cover and LST, which can effectively characterize the impact of different GI types on LST (Ogashawara \& Brum Bastos, 2012). At the same time, to minimize the redundancy with PD (Simpson, 1949), SIDI has a more intuitive explanation than Shannon's diversity index and has better statistical characteristics, which is less sensitive to the existence of rare GI types (McGarigal et al., 2002; Romme, 1982; Wu et al., 1997).

\subsubsection{Landscape complexity indicators of spatial configuration}

Studies have confirmed that different forms and complexity of urban spatial patterns have a significant effect on LST (Li et al., 2018; Zhou et al., 2011). In this study, the spatial configuration consists of PD, DIVISION, and FDI. PD refers to the number of patches per unit area, which represents the distribution density of GI patches, reflecting the heterogeneity of GI. DIVISION reflects the degree of patch aggregation by calculating the probability that two randomly selected objects are not in the same patch, which can be calculated at landscape and class level (Timm \& McGarigal, 2012). This algorithm circumvents the shortcomings of considering only the involved proximal focus classes, as well as the metrics, such as the algorithm of AI index (McGarigal et al., 2002). FDI refers to the ratio of the log of patch circumference to the log of patch area, which has a better explanation for irregular geometry (Danila et al., 2019). This algorithm can explain most ecological processes and natural phenomena driven by mathematical and physical models, which cannot be described by Euclidean geometry (Burn, 1984). It emphasizes the multidimensional relationship between the whole and the parts of GI (Meng et al., 2019), which can truly characterize the two-dimensional geometric morphology of non-regular space.

\subsection{Moving-window analysis}

As confirmed by previous research, the cooling effect of GI has a scale effect (Naeem et al., 2018), which means different window sizes will affect the accuracy of the calculation results. It has also shown the proportion of GI within a certain area is one of the key factors affecting the cooling effect (Venter et al., 2020). The percentage of GI (PGI) was selected to determine the optimal size of the window. Following the principle of avoiding the window to segment the complete GI patch while moving, the patch sizes needed to be clarified. In Taiyuan metropolitan area, the average GI patch was about $0.29 \mathrm{~km}^{2}$ (approximately $0.54 \times 0.54 \mathrm{~km}$ ), and $85 \%$ of patches were smaller than $0.9 \times 0.9 \mathrm{~km}$. Moreover, limited by the $30 \mathrm{~m}$ resolution of the data, the window size was set to an integer multiple of $30 \mathrm{~m}$. Therefore, $0.6 \times 0.6 \mathrm{~km}, 0.9 \times 0.9 \mathrm{~km}, 1.5 \times 1.5 \mathrm{~km}$, and $1.8 \times 1.8 \mathrm{~km}$ were selected to compare the relationship between LST and PGI at different sizes (Table 4).

If the size of moving window is too small, it will cut the complete patch, which means the cooling effect on LST will be miscalculated. On the contrary, the cooling effect of patches with fewer GI will be weakened. Meanwhile, the larger window size also means a reduction in the number of samples. It was important to realize that in the metropolitan area, the densely built-up area has a smaller average GI patch size than the green belt. Thus, to ensure the accuracy of the correlation results, $1.5 \times 1.5 \mathrm{~km}$ was chosen as the window size.

In summary, the Analysis parameters were set to the moving window mode in Fragstats software to calculate the landscape complexity indicators, except for TNI. The ModelBuilder tool in ArcGIS 10.3 was applied to construct the moving window method, and the average TNI in each window was calculated according to the formula, as well as the average LST (the average LST of each window was calculated by weighting the average LST of all rasters within the window range). The above moving windows were calculated by setting the conditions that the shape of the window was a square with a side length of $1.5 \mathrm{~km}$, and the horizontal moving distance of the window was one raster $(30 \mathrm{~m})$.

Table 4. Relationship between PGI and LST in different window sizes

\begin{tabular}{|c|c|c|c|c|}
\hline $\begin{array}{c}\text { Moving } \\
\text { window size }\end{array}$ & $\begin{array}{c}\text { Correlation } \\
\text { equation }\end{array}$ & $R^{2}$ & $p$ & $\begin{array}{c}\text { Number of } \\
\text { samples }\end{array}$ \\
\hline $600 \times 600 \mathrm{~m}$ & $y=1.83-0.05 x$ & 0.428 & $<0.01$ & 4161 \\
\hline $900 \times 900 \mathrm{~m}$ & $y=1.97-0.05 x$ & 0.464 & $<0.01$ & 1643 \\
\hline $1200 \times 1200 \mathrm{~m}$ & $y=2.56-0.06 x$ & 0.622 & $<0.01$ & 616 \\
\hline $1500 \times 1500 \mathrm{~m}$ & $y=2.58-0.06 x$ & 0.655 & 0.01 & 425 \\
\hline
\end{tabular}

\subsection{Definition and calculation of UCI intensity and TVoE}

Many studies have demonstrated the influence of the GI scale and the improvement of vegetation coverage on the 
UHI effect (Guo et al., 2019; Shi et al., 2020). Currently, most studies directly use LST of the study area obtained from the reversal as a measure of the GI cooling effect (Zhang et al., 2017b). Some articles quantify the specific cooling effect of GI by the difference between the regional LST and the study cell LST (Wu et al., 2020; Zhou et al., $2019 b$ ). In this study, the cooling intensity was used to represent the cooling capacity of GI, also known as urban cooling island (UCI) intensity. And the cooling efficiency was defined as a logistic curve between landscape complexity index and UCI intensity, which meant when the slope of the curve started to decrease after exceeding a point, this point was the threshold value of cooling efficiency (TVoE) (Augusto et al., 2020).

Based on the minimal research unit of the moving window, UCI intensity was calculated by the Min-Max Normalization method, with the difference value ( $\Delta \mathrm{LST}$ ) between the average LST of each moving window unit and the average LST of the two regions (Zhou et al., 2019b). In this study, $\Delta T_{m}$ was defined as the average LST of the densely built-up area and green belt respectively. The formula of the different value was: $\Delta \mathrm{LST}=\Delta T_{g}-\Delta T_{m}$, where $\Delta T_{g}$ represented the average LST of each window. TVoE was calculated by the logarithmic function curve between the complexity indicator (independent variable) of each window and the UCI intensity of the region where it was located. Specifically, according to the change of TVoE curve, the grid of different sizes was added to find the value of the complexity indicator corresponding to TVoE. As the landscape complexity index (independent variable) increased from small to large, before this TVoE point located on the curve, the rise of $\Delta \mathrm{LST}$ was obvious. After the point, the independent variable continued to increase, and the increased amplitude of $\Delta$ LST significantly decreased.

\subsection{Statistical analysis}

This study sought to explore the relationship between landscape complexity index and UCI intensity. On the one hand, analysis of variance (ANOVA) was used to identify the difference of LST fluctuation between the densely built-up area and the green belt. On the other hand, Pearson's correlation coefficient (PCC) was used to reflect the pairwise correlation between independent variables and the LST reduction. The principal component analysis was chosen to calculate the importance and weights of the indicators. At landscape level, statistical analysis was carried out to examine the relationship between TNI, SIDI, PD, FDI, and DIVISION of GI and UCI intensity. At class level, statistical analysis was to calculate the correlation between the complexity index of each GI type and UCI intensity, and TVoE of different GI types. All the correlations are analyzed by partial correlation analysis.

Based on SPSS26.0 and Excel software, min-max normalization was set that when the value of $\triangle \mathrm{LST}$ was smaller, the larger the normalized value was. Linear regression analysis was used to calculate the impact, with landscape complexity index as the independent variable, and UCI intensity as the dependent variable. And to calculate the importance and weight of the indicators, the values of the indicators were also normalized. Equation $\frac{x_{i}-\min }{\max -\min }$ was used for the indicators positively correlated with the UCI effect, and $\frac{\max -x_{i}}{\max -\min }$ was used for indicators with negative correlations. Finally, TVoE of different GI types were obtained by fitting logarithmic function curves formed by UCI intensity and complexity indicators.

Furthermore, to verify the accuracy of TVoE, the twoway equalization method was used on the $\mathrm{x}$-axis where PLAND was located. Firstly, based on the monotonically increasing nature of the logarithmic function and the threshold of "law of diminishing marginal utility", the data set of complexity indicators was divided into two equal levels, and the threshold was initially verified to be less than the middle value or not. The intermediate value was calculated from the maximum and minimum values of indicators. Simultaneously, after identifying the value of the indicator corresponding to TVoE, the interval from this value to 0 was divided into two levels equally. Dividing an interval into two levels can better ensure the continuity and credibility of the data compared to one level. On the basis of the interval of these two levels, two new levels with the same interval were partitioned on the $\mathrm{x}$-axis, where greater than TVoE. If the trends of the fitted curves in the pre-TVoE and post-TVoE levels were opposite, the calculation of TVoE was accurate. If not, TVoE needed to be recalculated.

\section{Results}

\subsection{Spatial characteristics of GI and relationship with LST}

The result showed that the distribution of LST was closely related to the spatial characteristics of the GI. It was similar to previous studies which proved that if GI had a larger area, it would have a higher cooling effect (Jiao et al., 2017). The GI of the densely built-up area and the green belt covered the area of $209.08 \mathrm{~km}^{2}$ and $655.16 \mathrm{~km}^{2}$ respectively, and the average LST () was $32.49{ }^{\circ} \mathrm{C}$ and $29.76^{\circ} \mathrm{C}$, with a difference of $2.73^{\circ} \mathrm{C}$. By matching with HD Google images, the highest LST points were found in the areas where factories were clustered: No. 1 Taiyuan Iron and Steel Group, No. 2 Taiyuan Heavy Machinery Group Corporation, No. 3 Foxconn Taiyuan Industrial Park, and No. 4 Beige Town, where had less GI coverage and consumed a lot of energy (Figure 2). As a result, these areas were highly susceptible to the heat island effect where the LST was much higher than the rest of the regions.

Meanwhile, considering the influence of the surrounding GI in the densely built-up area, as well as previous research experience, the area $500 \mathrm{~m}$ from the boundary line was excluded in this study as an interference zone (Du et al., 2017; Hamada \& Ohta, 2010). The $\Delta T_{m-r e}$ in the two regions were $31.63{ }^{\circ} \mathrm{C}$ and $29.41{ }^{\circ} \mathrm{C}$, which had 
Table 5. Descriptive statistics of LST in Taiyuan, 2019

\begin{tabular}{|l|c|c|c|c|c|c|c|c|c|}
\hline \multirow{2}{*}{\begin{tabular}{|} 
Location \\
\cline { 2 - 11 }
\end{tabular}} & \multicolumn{4}{|c|}{ LST $\left({ }^{\circ} \mathrm{C}\right)$} & \multicolumn{4}{c|}{ Average LST of GI $\left({ }^{\circ} \mathrm{C}\right)$} & \multicolumn{1}{c|}{$\begin{array}{c}\text { Average } \\
\text { LST of TIS } \\
\left({ }^{\circ} \mathrm{C}\right)\end{array}$} \\
\hline Densely built-up area & 54.31 & 27.33 & 32.49 & 31.63 & 32.92 & 30.44 & 31.67 & 28.63 & 33.62 \\
\hline Green belt & 38.24 & 26.29 & 29.76 & 29.41 & 30.64 & 29.17 & 30.03 & 27.13 & 30.84 \\
\hline
\end{tabular}

Note: Max. means the maximum value of LST; Min. means the minimum value of LST. TIS means the average LST of impervious surface.

been recalculated (Table 5). Compared with the impervious surface, the LST affected by UCI in the two regions were $1.99{ }^{\circ} \mathrm{C}$ and $1.43^{\circ} \mathrm{C}$. And excluding the waterbodies as areas with the lowest LST, the difference between the $\Delta T_{m-r e}$ of GI and the impervious surface is $2.7^{\circ} \mathrm{C}$ in the densely built-up area, while that in the green belt is $1.58^{\circ} \mathrm{C}$.

To gain a better understanding of the continuous change between GI and LST, the east-west (E-W) and south-north(S-N) directions were selected with a cut line each with the 3D Analyst tool in ArcGIS (Figure 2a). Figure 3a showed the line crossed the West Mountain and the southern part of densely built-up area, having a trend of stable fluctuations of LST within the range of GI such as forests and shrubs. When transitioning from GI to the impervious surface, LST increased significantly. Along with the W-E profile, the variance of LST in the two regions were 10.18 and 5.24. Kurtosis of the densely built-up area (2.78) was higher than the green belt (0.98), which indicated that the LST fluctuation of the green belt on the W-E was smaller than that of the densely built-up area. Figure 3b showed that the LST of GI in densely built-up areas was slightly higher than the GI in the green belt. The extremely low value of LST occurred in the forest of the densely built-up area, and the high values occurred in the farmland near the development zone. Along with the S-N profile, the variance of LST on the two regions were 7.72 and 6.91, which meant the fluctuation of LST was similar.

\subsection{Influence of landscape complexity on GI's cooling effect at landscape level}

By comparing the relationship between the landscape complexity of GI and the cooling effect, the correlation

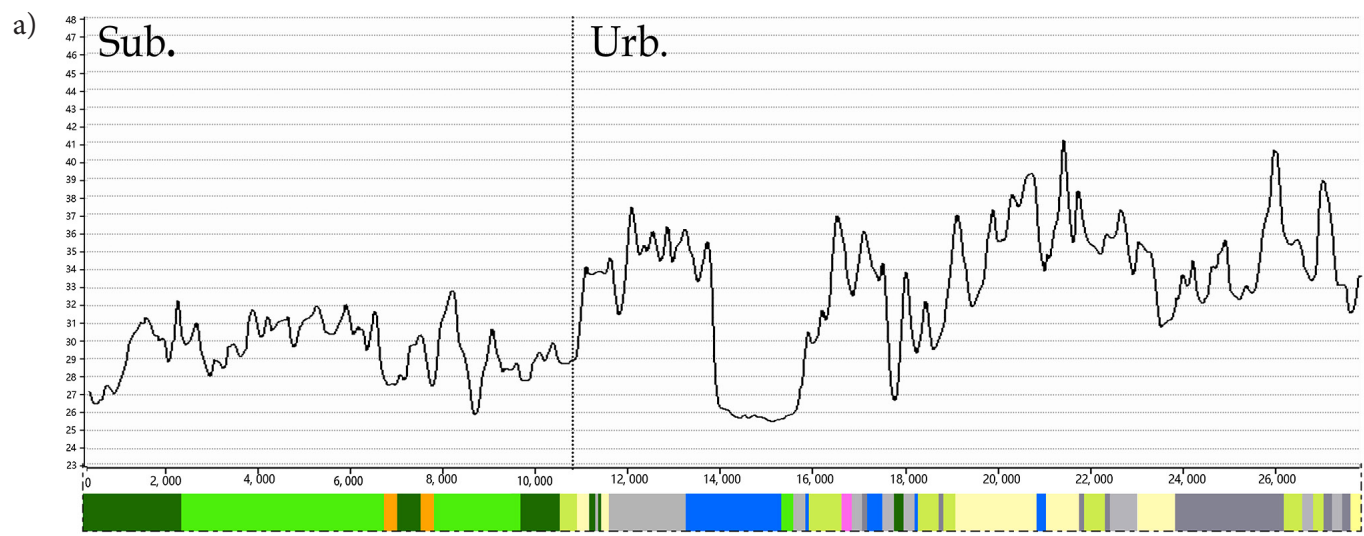

b)

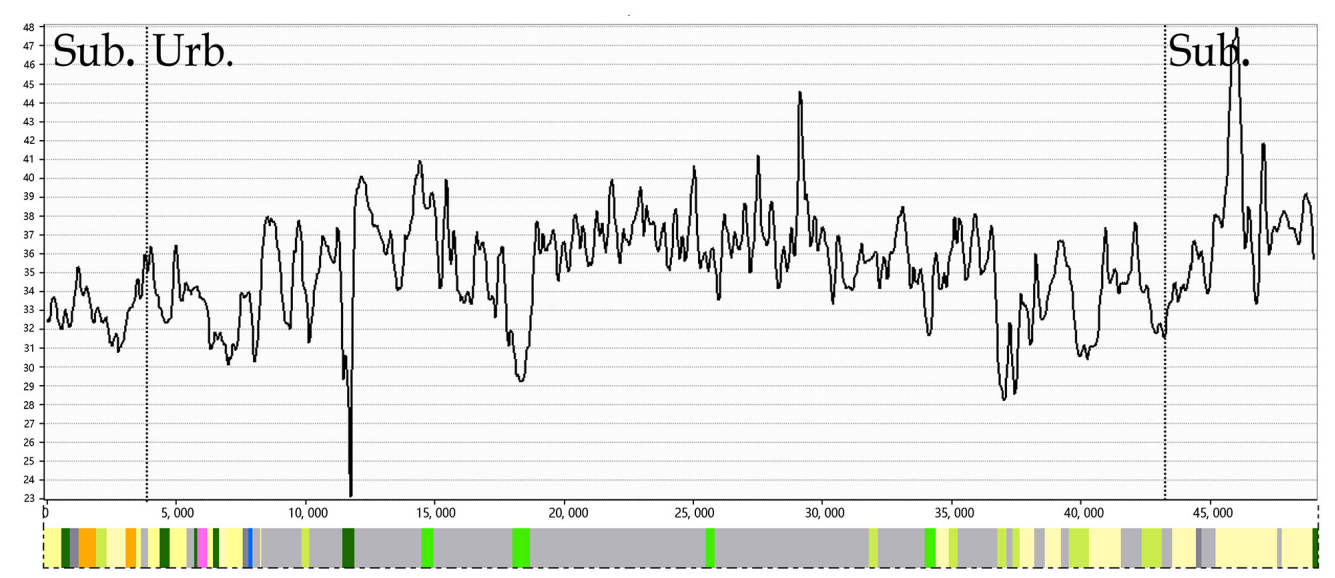

Figure 3. (a) The trend of LST and land use along with the W-E profile; (b) The trend of LST and land use along with the N-S profile. Urb. means the densely built-up area; Sub. means the green belt. The legend is the same as in Figure $2 \mathrm{~b}$ 
Table 6. Relationships between landscape complexity index and UCI intensity

\begin{tabular}{|l|c|c|c|c|c|c|}
\hline \multirow{2}{*}{ Zone } & Measure & TNI & SIDI & PD & FDI & DIVISION \\
\hline \multirow{2}{*}{$\begin{array}{l}\text { Densely built-up } \\
\text { area }\end{array}$} & PCC & 0.035 & $0.285^{* *}$ & $0.352^{*}$ & $-0.385^{* *}$ & $0.231^{* *}$ \\
\cline { 2 - 7 } & $\mathrm{p}$ & 0.549 & 0.000 & 0.038 & 0.002 & 0.000 \\
\cline { 2 - 7 } & Weights & 0.15 & 0.23 & 0.21 & 0.17 & 0.24 \\
\cline { 2 - 7 } Green belt & PCC & $0.728^{* *}$ & -0.069 & $-0.213^{* *}$ & $-0.376^{* *}$ & $-0.086^{* *}$ \\
\cline { 2 - 7 } & Weights & 0.000 & 0.073 & 0.000 & 0.000 & 0.19 \\
\hline
\end{tabular}

Note: ${ }^{* *}$. at 0.01 level (two-tailed), significant correlation; ${ }^{*}$. at 0.05 level (two-tailed), significant correlation.

results of the densely built-up area and the green belt had some differences (Table 6). For the densely built-up area, the result indicated that there was no significant correlation between the cooling effect of GI and TNI. As the only indicator of landscape composition at landscape level, SIDI had a strong influence on cooling the UHI, which was consistent with the value of the weights (Figure 4a, Table 6). Meanwhile, among the spatial configuration indicators, the positive correlation between PD and UCI intensity $\left(R^{2}=0.213, p<0.05\right)$ and the positive correlation between DIVISION and UCI intensity $\left(R^{2}=0.053\right.$, $p<0.05$ ) indicated that a discrete and high patch density of GI was likely to have greater cooling effects than a smaller number of aggregated GI. FDI, as the ratio of patch circumference to the area, reflected that GI with simpler form had a stronger cooling effect (Figure 4a).

For the green belt, the topography of GI had considerable influence on the cooling effect, which meant that GI in complex terrain had a positive effect on alleviating the UHI effect, such as high-altitude forests and bushes on large slopes. According to the curve in Figure 4b, the equations of FDI and LST were as follows: $y=1.18-0.95 \cdot x$ $\left(R^{2}=0.134, p<0.05\right)$, which showed when the value of FDI was bigger than 1.2 and tended to 1 , UCI intensity gradually increased. The equation of DIVISION and UCI intensity was as follows: $y=1.6-0.06 \cdot x \quad\left(R^{2}=0.047\right.$, $p<0.05)$, which showed when the value of DIVISION was larger, the cooling effect gradually decreased. According to the weights, the importance of DIVISION together with TNI for UCI intensity was $48 \%$, nearly half, although the distribution of GI was less correlated with the cooling effect. Thus, in this case, aggregated configuration and a simple form of GI had a better cooling effect in the green belt (Table 6).

The calculation of multiple sets of data showed that the cooling effect of GI was closely related to the topography and configuration. Comparing the relationship between landscape complexity index and UCI intensity in the two regions, it found that GI with a simpler form tended to have a better cooling effect at landscape level. The more aggregated configuration the GI is in the green belt the better its cooling effect, which is the opposite of the densely built-up area.

\subsection{Influence of landscape complexity on UCI intensity at class level}

To further explore the influence of landscape complexity index on UCI's cooling efficiency, and calculate TVoE, this study selected the indicators which had a significant correlation with UCI intensity to identify the difference between the densely built-up area and the green belt. It should be noted that the landscape complexity of farmland and waterbody in cities was more affected by human activities and climate than the other GI types. Therefore, in the arid city, forest and grassland were taken as the main research object.

In the densely built-up area, UCI intensity was significantly positively correlated with the PLAND of farmland, forest, and waterbody, and significantly negatively a)

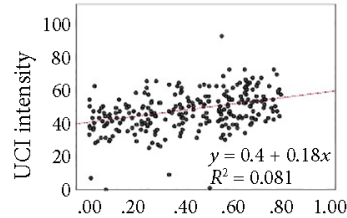

SIDI

b)

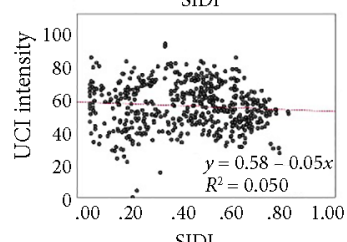

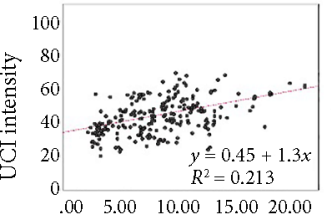

$\mathrm{PD}$

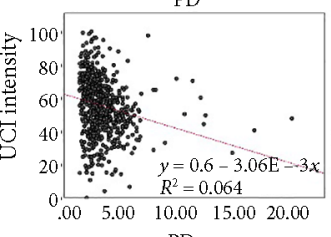

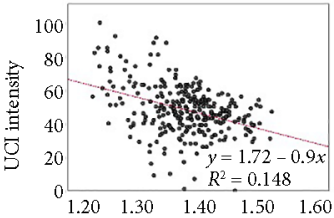

FDI

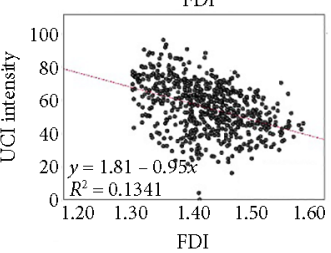

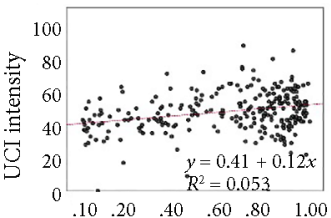

DIVISION

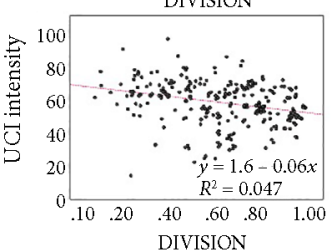

Figure 4. (a) Relationship between landscape complexity index and UCI intensity in the densely built-up area; (b) Relationship between landscape complexity index and UCI intensity in the green belt 
correlated with the DIVISION of farmland, forest, and waterbody (Table 7). This indicated that water bodies with high specific heat capacity properties, as well as forests with abundant greenery possessed a great cooling effect. Meanwhile, the farmland with seasonal variation in crops possessed a slightly lower cooling potential than forests in the context of this study. As shown in Figure 5, the forest with a distribution of aggregation and the high percentage area had a better cooling effect than the fragmented one, and the logarithmic function of UCI intensity and PLAND-Forest was: $\mathrm{y}=0.0577 \ln (\mathrm{x})+0.346\left(R^{2}=0.2329\right.$, $p<0.01)$. Results showed that when the value of PLAND was from $2 \%$ to $0 \%$, the curve was very steep, indicating that cooling efficiency increased rapidly with the increase of forest area proportion in this interval. However, as the proportion of forest area increased larger, the red line tended to be horizontal, meaning that cooling efficiency gradually decreased and approached a stable value indefinitely.

Furthermore, the two-way equalization method was used to verify TVoE. Firstly, in the densely built-up area, the maximum PLAND value was about $60 \%$ and the minimum value was tending to be 0 , which meant the intermediate value was $30 \%$. It showed that $\mathrm{TVoE}$ was less than $30 \%$ in Figure 6. Meanwhile, TVoE was $2 \%$, which indicated that the PLAND-Forest was divided into 6 levels: PLAND.1 (0-1\%), PLAND.2 (1-2\%), PLAND.3 (2-3\%), PLAND.4 (3-4\%), PLAND.5 (4-30\%) and PLAND.6 $(>30 \%)$. Although the bivariate correlations in some subplots were not high, the linear trends before and after the $2 \%$ had verified the accuracy of TVoE. Figure 6 indicated that PLAND had indicated that the relationship between PLAND and UCI intensity showed an opposite trend before and after the value of $2 \%$. The result verified the credibility of TVoE, but also showed that under the same research unit, the cooling effect increases with the area of forest.

In the green belt, the impact of the spatial configuration indicators of the forest with UCI intensity was significant, and PLAND of the forest had a greater impact on the cooling effect, which was similar to the results of the densely built-up area (Table 7). The result showed in Figure 7 that when the red line exceeded the PLAND
Table 7. Relationships between landscape complexity of various GI types with UCI intensity

\begin{tabular}{|c|c|c|c|c|c|}
\hline Zone & Indicator & GI type & PCC & $\mathrm{p}$ & Weights \\
\hline \multirow{12}{*}{$\begin{array}{l}\text { Densely } \\
\text { built-up } \\
\text { area }\end{array}$} & \multirow{4}{*}{ FDI } & Farmland & $0.242^{*}$ & 0.016 & 0.244 \\
\hline & & Forest & 0.015 & 0.876 & 0.233 \\
\hline & & Grassland & 0.070 & 0.735 & 0.232 \\
\hline & & waterbody & $-0.450^{* *}$ & 0.000 & 0.291 \\
\hline & \multirow{4}{*}{ DIVISION } & Farmland & $-0.276^{* *}$ & 0.000 & 0.222 \\
\hline & & Forest & $-0.276^{\star *}$ & 0.000 & 0.268 \\
\hline & & Grassland & -0.097 & 0.260 & 0.237 \\
\hline & & waterbody & $-0.474^{* *}$ & 0.000 & 0.273 \\
\hline & \multirow{4}{*}{ PLAND } & Farmland & $0.291^{* *}$ & 0.000 & 0.229 \\
\hline & & Forest & $0.396^{* *}$ & 0.000 & 0.248 \\
\hline & & Grassland & 0.134 & 0.118 & 0.220 \\
\hline & & waterbody & $0.616^{\star *}$ & 0.000 & 0.303 \\
\hline \multirow{12}{*}{$\begin{array}{l}\text { Green } \\
\text { belt }\end{array}$} & \multirow{4}{*}{ FDI } & Farmland & $-0.252^{* *}$ & 0.000 & 0.278 \\
\hline & & Forest & 0.042 & 0.359 & 0.217 \\
\hline & & Grassland & -0.081 & 0.345 & 0.300 \\
\hline & & waterbody & $-0.116^{\star *}$ & 0.010 & 0.205 \\
\hline & \multirow{4}{*}{ DIVISION } & Farmland & $0.221^{\star *}$ & 0.000 & 0.243 \\
\hline & & Forest & $-0.656^{* *}$ & 0.000 & 0.315 \\
\hline & & Grassland & 0.084 & 0.063 & 0.133 \\
\hline & & waterbody & $-0.290^{* *}$ & 0.000 & 0.309 \\
\hline & \multirow{4}{*}{ PLAND } & Farmland & $-0.290^{* *}$ & 0.000 & 0.225 \\
\hline & & Forest & $0.743^{\star *}$ & 0.000 & 0.249 \\
\hline & & Grassland & $0.323^{* *}$ & 0.000 & 0.280 \\
\hline & & waterbody & $0.096^{*}$ & 0.034 & 0.246 \\
\hline
\end{tabular}

Note: ${ }^{* *}$. at 0.01 level (two-tailed), significant correlation; ${ }^{*}$. at 0.05 level (two-tailed), significant correlation.

value of $4 \%$, the slope of the curve started to decrease, which meant TVoE of PLAND was 9 ha. And the range of PLAND value was from 0 to $100 \%$. To verify the result, the value of PLAND was divided into 6 levels: PLAND.1 (0-2\%), PLAND.2 (2-4\%), PLAND.3 (4-6\%), PLAND.4 (6-8\%), PLAND.5 (8-50\%) and PLAND.6 (>50\%). Specifically, as Figure 8 showed, the PLAND-Forest had a
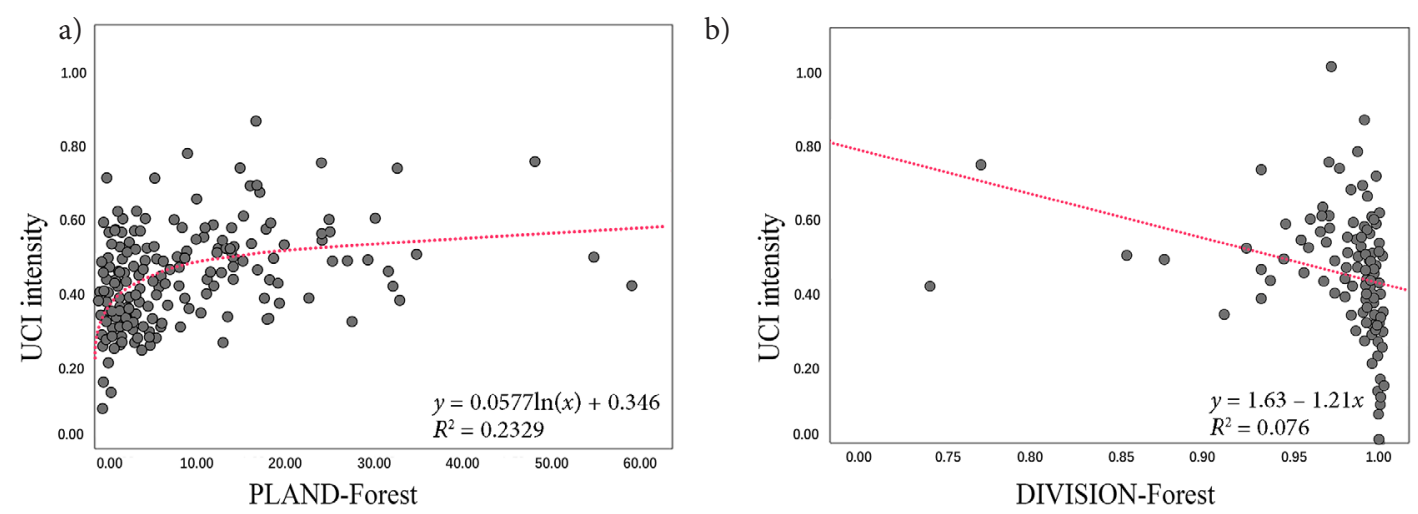

Figure 5. (a) The result of UCI intensity and TVoE of PLAND-Forest in the densely built-up area; (b) Relationship between UCI intensity and DIVISION-Forest in the densely built-up area 

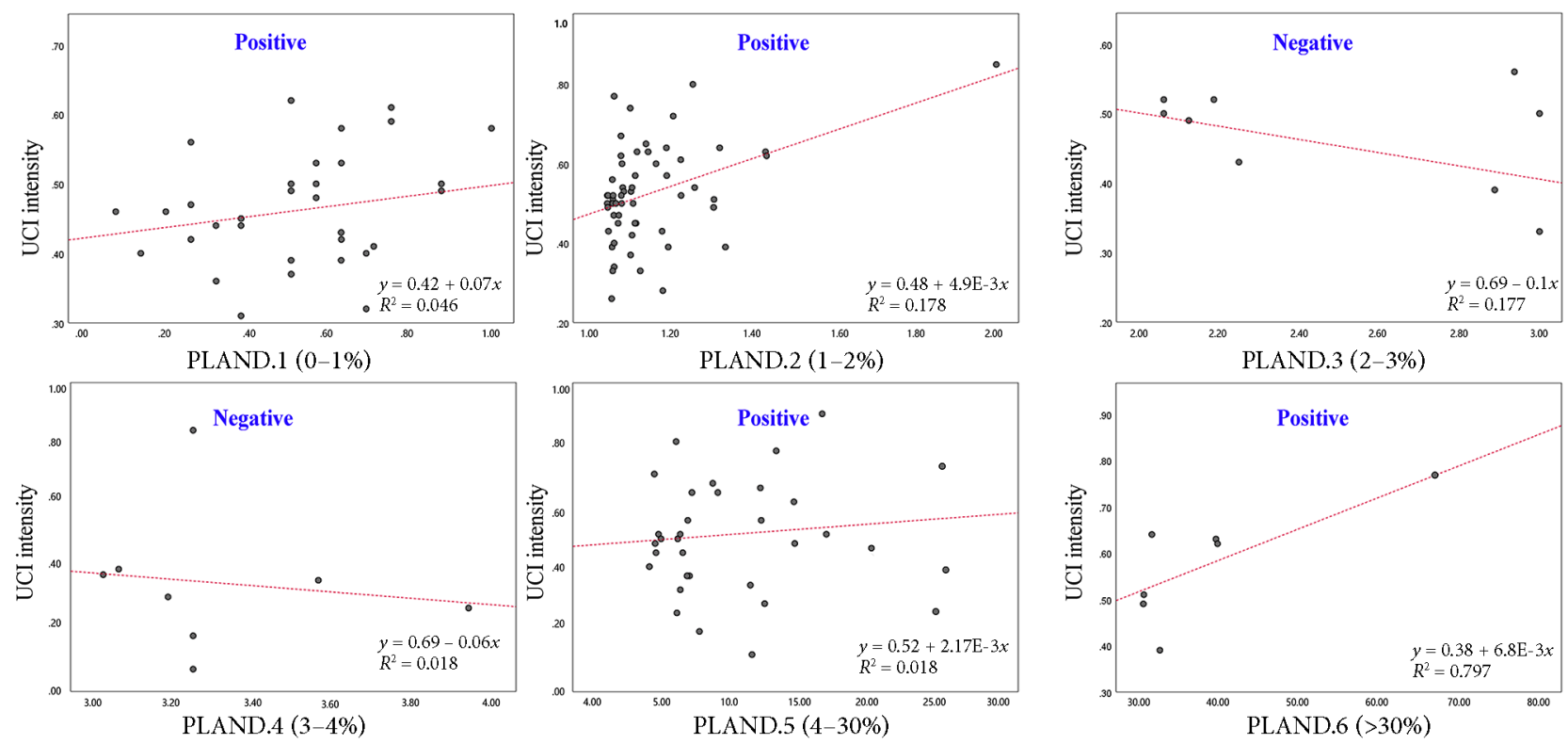

Figure 6. Verification of TVoE on PLAND-Forest in the densely built-up area

trend of positive relationship within $0-4 \%$, and this linear relationship became negative when the value became $4-8 \%$. Meanwhile, the cooling effect decreased as the DIVISION values of the forest rose, which meant that if the large area forest had an aggregated spatial structuration, it could provide a better cooling effect.

Unlike the densely built-up area, PLAND of grassland in the green belt had a significant correlation with UCI intensity (PCC $\left.=0.323^{* *}, p<0.01\right)$. Based on TVoE, it showed that the value of threshold was in the interval of less than 50\% PLAND-Grass. Thus, the PLAND-Grass was divided into 6 levels: PLAND.1 (0-0.5\%), PLAND.2 (0.5$1 \%)$, PLAND.3 (1-1.5\%), PLAND.4 (1.5-2\%), PLAND.5 (2-50\%) and PLAND.6 (>50\%) (Figure 10). The results showed that the relationship between PLAND-Grass and UCI intensity had an opposite trend before and after the value of 1\% (Figure 10). However, we found in PLAND.5 that increasing the grass area did not necessarily exist the cooling effect. This was related to the limitation of the sample size and the division of the sample area, which

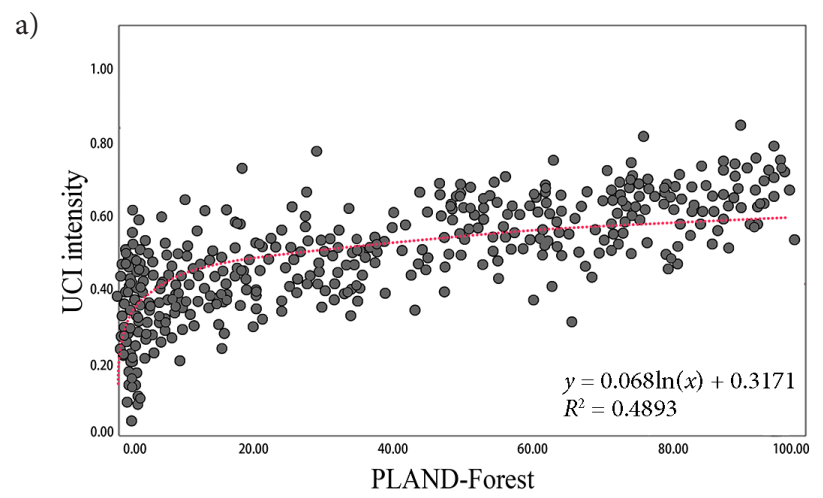

might not truly reflect the influence of grassland on UCI intensity.

The calculation of PLAND (Figure 5, 7, and 9) indicated that, in an area of $1.5 \times 1.5 \mathrm{~km}, 2 \%$ of forest area in the densely built-up area, $4 \%$ of forest area, and $1 \%$ of grassland area in the green belt had the highest cooling efficiency, which confirmed that forest with a compact distribution owned the good cooling effect, in this arid basin city.

\section{Discussion}

\subsection{Relationships between the UCI intensity and different types of GI}

The results showed that in the densely built-up area, GI with multiple types of dispersed distribution and having a simple shape can significantly reduce LST, while in the green belt GI with aggregated configuration and a simple form has a better cooling effect. Meanwhile, the larger and more densely distributed a forest is, the greater its ability

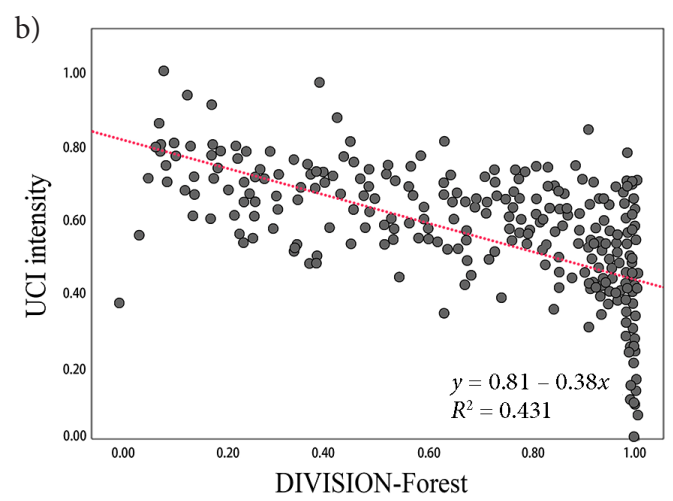

Figure 7. (a) The result of UCI intensity and TVoE of PLAND-Forest in the green belt;

(b) Relationship between UCI intensity and DIVISION-Forest in the green belt 

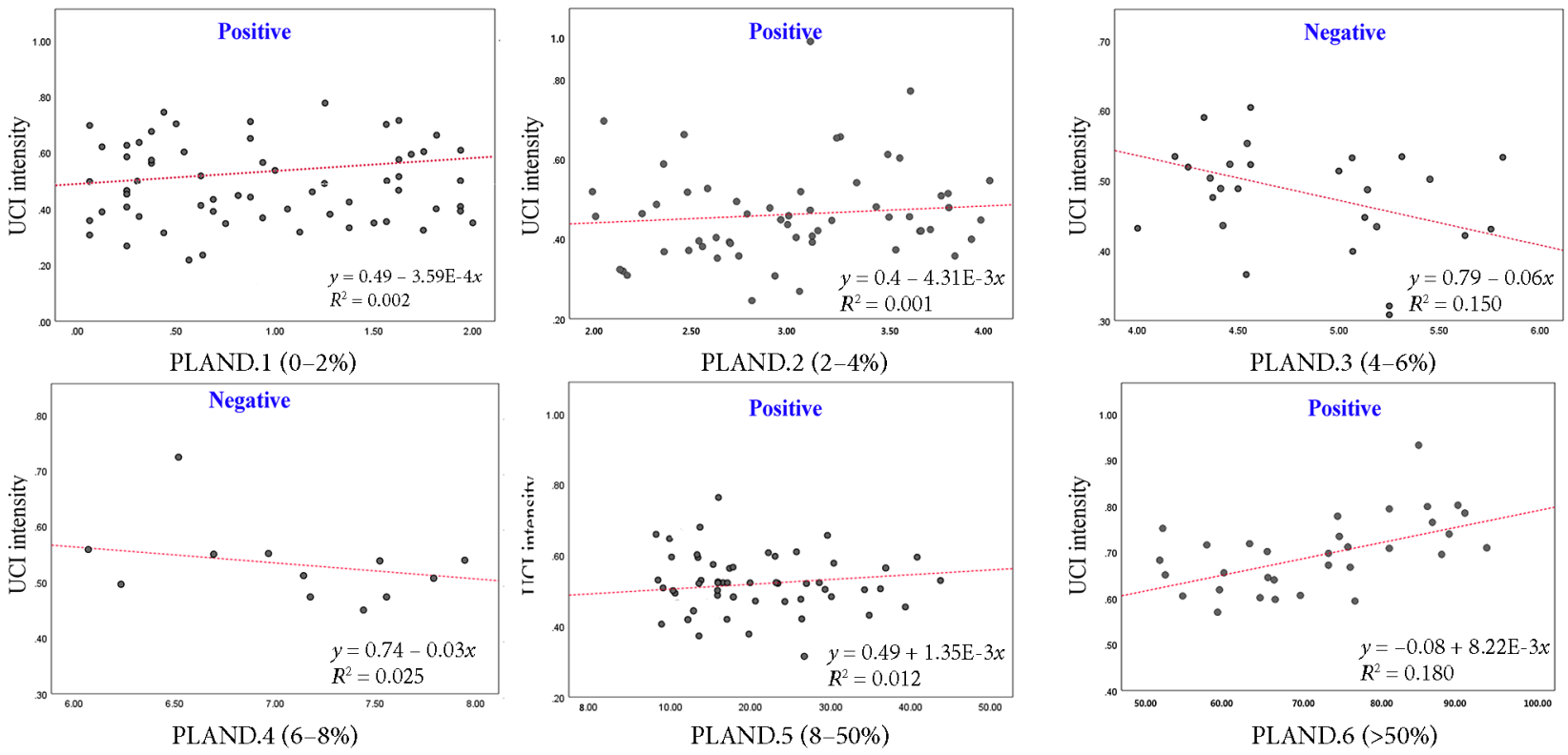

Figure 8. Verification of TVoE on PLAND-Forest in the green belt

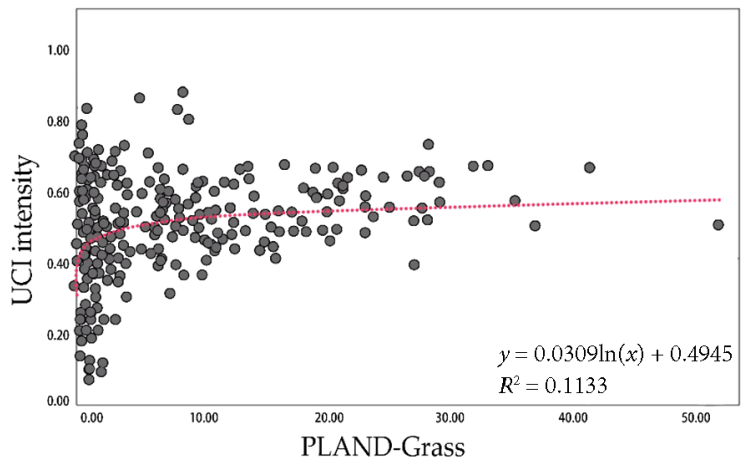

Figure 9. The result of UCI intensity and TVoE of PLAND-Grass in the green belt
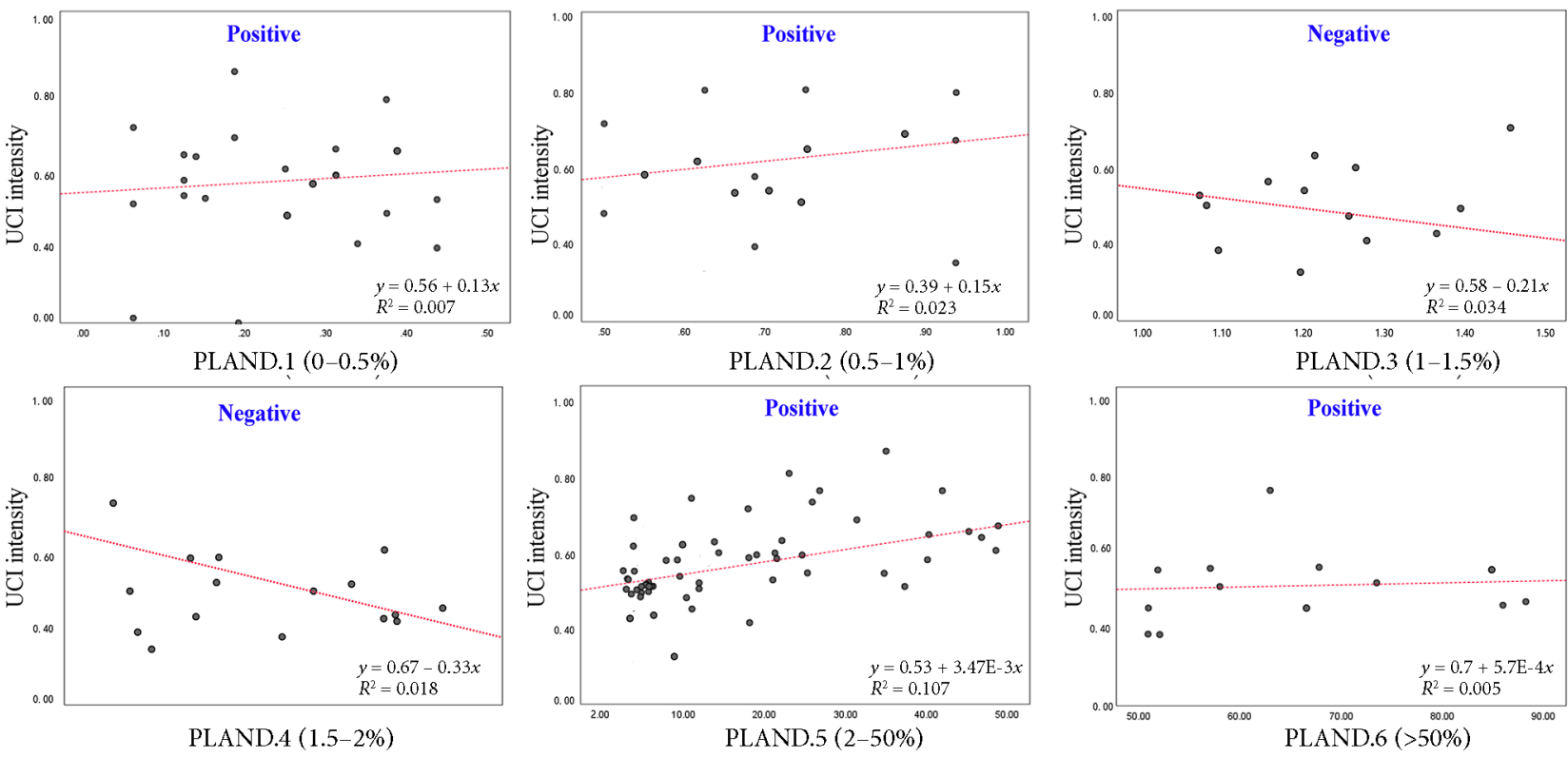

Figure 10. Verification of TVoE on PLAND-Grass in the green belt 
to mitigate the UHI effect. This study clearly explains the dependence of UCI intensity on different GI types, and these differences include internal structural characteristics of GI and external environmental characteristics. On the one hand, the TNI was an important indicator of the environmental characteristics, which had a strong positive correlation with UCI intensity in the green belt. It includes the impact of different geographical environments on the UCI intensity of GI such as the plain and mountain. For instance, with the elevation increasing, the relative temperature of the land surface tends to decrease (Novikmec et al., 2013), which explains that different elevations and slopes show strong interactions with other ecological factors to enhance the cooling effect. A study in Hangzhou has also been argued that the shading, slope direction, slope, and elevation of the mountain are linearly correlated with LST. And the more shading formed, the lower the LST of the corresponding region (Peng et al., 2020). These shading effects, thermal mass effects, obstruction of airflow, and latent heat exchange due to the formation of the mountain's vertical features can have an impact on the variation and identification of regional LST, and are subject to more in-depth study (Equere et al., 2021).

However, within the densely built-up area located in the river valley, the topography is less undulating and space is flatter, which explains the relationship between TNI and UCI intensity is not significantly correlated.

On the other hand, FDI and DIVISION, as indicators of spatial structure within the GI, were important drivers of regional LST at landscape level (Table 6). FDI was significantly negatively correlated with the UCI intensity and DIVISION had a significantly positive correlation in the densely built-up area, which was the opposite of the results from the green belt. These results differed from the findings of Chinese cities with a humid climate such as Suzhou and Changsha (Weng et al., 2007; Zhang et al., 2017b). It suggested that the cooling effect of the spatial configuration was influenced by humidity as a climatic factor, as also argued in the study of Rasul et al. (2015). The simple shape of the GI reduced the contact surface with the surrounding land, thus reducing the influence from the outside on the cooling effect of GI (Kong et al., 2014b). The difference in the relationship between DIVISION and the cooling effect in the two regions showed a high correlation between the cooling effect and the land surrounding the GI, which meant the dispersed GI could effectively cool the UHI.

However, the dispersed GI was also more susceptible to the influence of heat sources. The higher the number of heat sources and maximum temperature in the densely built-up area compared to the green belt, the greater its effect on the dispersed GI. Therefore, the aggregated GI in the densely built-up area might have a better cooling effect. As some studies have shown that clustering or less fragmented patterns of green space are more effective at reducing LST than dispersive patterns (Fan et al., 2015). It is noteworthy that some of the studies took different methods. For example, an article used the Normalized Compactness Index to calculate the arrangement of GI in the Beijing metropolitan region (Zhang et al., 2017c). The core algorithm for this indicator was the Euclidean distance, which equated disparities between different attributes of a sample. And the result was that if the area became smaller, the denser the green patch, the cooling effect would weaken. A result of another study showed that the uniformly distributed green space has a greater cooling effect, rather than the aggregation of large areas of green space in Baotou (Bao et al., 2016). It used the knearest neighbor algorithm to calculate the nearest neighbor index based on the mean distance from each feature to its nearest neighboring feature. The algorithm in this study was explained in section 2.3. This kind of difference may be due to the different algorithms, and the climatic characteristics of the different study areas, which should be clarified with contrast experiments in the same space.

Furthermore, this study explored that within a unit area, forests with more aggregated distribution and larger area proportion showed a better cooling effect, and there was TVoE of GI in the two regions. The concept of TVoE is from the "law of diminishing marginal utility" in economics (Zhang et al., 2019). In terms of the landscape complexity index, different GI types need a minimum value to achieve the cooling effect, which represents that if the value exceeds the threshold, the cooling efficiency decreases. In this study, the results were consistent with existing research, which showed that if the percentage of forest area was higher, the UCI intensity would be stronger. And when the area percentage of the forest increased by $10 \%$, the LST decreased by about $0.83{ }^{\circ} \mathrm{C}$ (Kong et al., 2014a). Within the range of $1.5 \times 1.5 \mathrm{~km}, \mathrm{TVoE}$ of PLANDForest in the densely built-up area was calculated to $2 \%$, about 4.5 ha. And this indicator's value in the green belt was $4 \%$, about 9 ha. For example, in cities with humid climates at low latitudes, when the vegetation is rich and healthy, and the temperature of GI patches is high, 0.920.96 ha patches have the optimal cooling effect (Fan et al., 2019). TVoE of the Chinese city Fuzhou is 4.55 ha (Yu et al., 2017). This difference value of TVoE has a certain relationship with the geographical environment. Due to the lack of surface water resources, it is impossible to effectively connect the blue-green infrastructure (Sun et al., 2018).

The result also found that the grassland with compact configuration and simple shape could effectively reduce LST in the green belt. Understandably, grassland has a lower impact on cooling effect than forest (Table 7), based on the fact that forest has more complex plant matching and structure than grass and shrubs (Masoudi \& Tan, 2019). Plants improve LST by shading the canopy and transpiration of leaves (Rahman et al., 2017). The increase of forest area proportion undoubtedly enhances the transpiration of vegetation and the mean humidity of the region, which has been confirmed by Rasul et al. (2015) studying of cities in the dry season. 


\subsection{Implications for GI planning strategies}

Studies in the past had proved that adjusting the area and structure of green space could effectively reduce the LST. A strong correlation between the cooling effect and the indicators such as the shape, size, and distance of green space had been demonstrated (Rahman et al., 2015). At landscape level, the results of this study showed that a scattered GI system with the simple form and rich GI composition in the densely built-up area, and a compact GI system with the simple form and less diversity of GI types in the green belt might be the most practical and efficient way to cool the UHI (Figure 4), which were consistent with the results of some articles, such as the fractal dimension and distribution of GI had a positively correlated with the cooling effect in Maryland (Zhou et al., 2011), and the UCI intensity was negatively correlated with the dispersive distribution of GI in Tehran (Bokaie et al., 2016). The findings of this study did not represent the best way to mitigate the UHI in all cities, but were still highly informative for comparative analysis of study areas, especially for cities with similar latitudes.

Further, regarding the effect of GI on regional UHI, there had been many studies showing a positive correlation between GI size and UCI effects, but this pattern was not fixed (Bowler et al., 2010; Monteiro et al., 2016). And some papers documented that there was a threshold for the UCI effect of the greenfield scale (Du et al., 2017; Sun \& Chen, 2012). It's worth noting that in the constant area of green space, the number of green patches could increase or decrease the regional LST in Changchun, depending on whether the number was larger than a threshold (Yang et al., 2017).

In this study, the threshold value of efficiency of the forest was 4.5 ha in the densely built-up area. This result is very similar to two other cases where $4.55 \pm 0.5$ ha and 5 ha were revealed to be the optimal green space size for cooling, respectively (Zhang et al., 2017c; Jia, 2009). It also found that GI with simple and dispersed morphology had better UCI intensity. However, according to the laws of urban development, it shows that the proportion of construction land area in the densely built-up area will be continuously increasing, which will lead to a massive reduction of the forest. Therefore, for urban planning and management in the densely built-up area of Taiyuan, forests are considered as the main type in the GI composition, and the cooling effect can be enhanced by designing a regular shape and controlling the area of individual patches to $4.5 \mathrm{ha}$. Meanwhile, increasing the degree of aggregated will fortify the energy and information exchange of the forest to the surroundings, and enhance the cooling effect (Oliveira et al., 2011).

For the green belt, TVoE of the forest area and grassland areas were 9 ha and 2.25 ha respectively, but this did not mean that GI should be limited to this scale to form the UCI. TVoE in the green belt is used as a lower limit for the patches' area, which is different from the thresholds in the densely built-up area. TVoE is set in the main ecological space of the city to safeguard the aggregation and integrity of GI patches and to prevent fragmented green spaces caused by over-urbanization. For example, with sufficient land, large integrated country parks and woodlands can be planned to provide more ecosystem services to the region. To increase the area of GI in high latitudes and large slopes to encourage privately contracted woodland conservation, rather than competing with older urban areas (Maimaitiyiming et al., 2014). Insisting on strict control of GI in the green belt, gradually increasing the forest coverage area will provide cool islands for the entire city (Wang et al., 2019b). Unlike the densely built-up area, the landscape complexity of grassland is also one of the important factors for reducing LST in this region. Increasing the proportion of grassland area can effectively cool the UHI. Furthermore, the cooling effect of the distribution and shape of grassland should also be paid attention to. Although the correlation between these indicators and the UCI intensity is not significant, the law of influence is consistent, both of the two regions. Especially, in the cities with an arid climate, this kind of correlation has some reference value for GI planning (Myint et al., 2015).

Therefore, for the GI planning and management of the Taiyuan metropolitan area, about 4.5 ha is the most effective size of forest in the densely built-up area to reduce LST. The 9 ha of forest area and 2.25 ha of grassland area have the most optimum cooling effect in the green belt. At the same time, it should also be considered that a simple form of GI should be arranged dispersedly and combined with multiple types in the densely built-up area, and a simple form of GI should be arranged centrally with high TNI in the green belt. While the area located in the junction of the two regions, is frequently affected by urban development, more research is still needed. The method of this study is valuable for dividing the best research unit and TVoE of GI.

\subsection{Limitations and future research}

It should be noted that there are some limitations to this study. Firstly, limited by the cloud cover of remote sensing images in the study area, this study selects one remote sensing image in the early morning of summer 2019 as the basic data of land use. The selection of one single data set ignores comparative analyses of UCI at different times, such as seasons and day-night, which can affect the UCI effect (Peng et al., 2018). Secondly, LST was influenced by many dynamic factors, such as natural and human activities. Thus, the influence of landscape complexity on LST and the threshold of the presence of GI area in the region proposed in this study might be applicable in regions where the context of season, geographic environment, and urban development was similar to that of the Taiyuan metropolitan area. Thirdly, even for the same type of GI, the different plant growth quality can affect the UCI effect at smaller scales. Although the vegetation characteristics of the two regions in this study were relatively similar, 
the relationship between plant species selection and system construction was not explored in depth. This study highlights the UCI effect of different GI in the densely built-up area and green belt. However, the UHI effect, as a class of climate phenomena mainly generated by urban development and population concentration, is influenced by various factors, such as urban morphology, climate, geographic location, GI composition and configuration, as well as socio-economic factors like population density and per capita income (Shishegar, 2015). This is one of the most important ecological concerns for future urban planning. For the UCI effect to have wider applicability and to achieve upgrades from urban to a global scale, UCI should be understood in different scenarios. Some of these studies have shown different UCI patterns by comparing warm and humid (subtropical monsoon climate) with warm and dry (Mediterranean climate) cities (Akbari \& Kolokotsa, 2016). Some other articles have focused on the impact of the socio-economic sector on the UHI (Li et al., 2020). In fact, Nature has also published a study on the UHI effect on population and climate, which shows that increase green cover and albedo are more effective in arid regions (Manoli et al., 2019). Therefore, not only green space pattern and plant growth quality influence the UCI effect, but the analysis of climate, geographic location, and socio-economic factors play a crucial role in further understanding the UCI effect.

\section{Conclusions}

For cities like Taiyuan, with the arid climate, water resources are scarce and land use is tight. Urban planners cannot demolish a large number of existing buildings and roads to alleviate the UHI effect. Meanwhile, as we all know, GI planning at the metropolitan scale is the result of constantly weighing urban land use and environmental sustainability. Therefore, in this study, based on the "Law of diminishing Utility", cooling efficiency and UCI intensity are identified, and TVoE is verified in the landscape complexity index of forest and grassland, which provides credible and operational information for urban planners and policymakers.

Practically, for the densely built-up area, forest with large area proportion and aggregated distribution has a good cooling effect, and TVoE of forest is about 4.5 ha. However, the densely built-up area has a high-density residential environment, which means the space for GI is quite limited. Thus, based on the premise of determining the proportion of the GI area, the three-dimensional green capacity of the specific space could be increased, such as replacing the traditional single-plane greening model with a three-dimensional greening layout model (Duncan et al., 2019; Sookhan et al., 2018). For the green belt, forest and grassland patches should be guaranteed to be larger than 9 ha and 2.25 ha, and make them spatially aggregated, especially in areas with high topography and undulating terrain. These conclusions are valuable to urban planning and GI management. This study selected an arid city as an example to demonstrate the reliability and feasibility of landscape complexity index on GI's cooling effect. Such methods can be applied to assess TVoE of the GI spatial structures and landscape configurations in other cities.

Undoubtedly, city planners and policymakers can use specific control strategies to mitigate the UHI effect in future land planning according to the correlations between the indicators and UCI intensity. Especially for the arid cities, compared with increasing the area of waterbody and green space only, adjusting the landscape complexity of GI is a more economical and effective way to reduce LST and achieve environmental sustainability.

\section{Acknowledgements}

The authors appreciate so much Bureau of Planning and Natural Resources, Taiyuan, for providing the research data. Also, the authors would like to express the appreciation to the anonymous reviewers and the editors.

\section{Conflicts of interest}

The authors declare no conflict of interest.

\section{Funding}

This work was supported by China National R \& D Program "Research on technology of ecological landscape in countryside" [grant number 2019YFD1100405]; and Fundamental Research Funds for Central University "Land Ecological Planning and Its Environmental Effects" [grant number 22120200082].

\section{References}

Akbari, H., \& Kolokotsa, D. (2016). Three decades of urban heat islands and mitigation technologies research. Energy and Buildings, 133, 834-842.

https://doi.org/10.1016/j.enbuild.2016.09.067

Augusto, B., Roebeling, P., Rafael, S., Ferreira, J., Ascenso, A., \& Bodilis, C. (2020). Short and medium- to long-term impacts of nature-based solutions on urban heat. Sustainable Cities and Society, 57, 102122. https://doi.org/10.1016/j.scs.2020.102122

Bao, T., Li, X., Zhang, J., Zhang, Y., \& Tian, S. (2016). Assessing the distribution of urban green spaces and its anisotropic cooling distance on urban heat island pattern in Baotou, China. ISPRS International Journal of Geo-Information, 5(2), 12. https://doi.org/10.3390/ijgi5020012

Bartesaghi Koc, C., Osmond, P., \& Peters, A. (2018). Evaluating the cooling effects of green infrastructure: A systematic review of methods, indicators and data sources. Solar Energy, 166, 486-508. https://doi.org/10.1016/j.solener.2018.03.008

Berardi, U., Ghaffarian Hoseini, A. H., \& Ghaffarian Hoseini, A. (2014). State-of-the-art analysis of the environmental benefits of green roofs. Applied Energy, 115, 411-428. https://doi.org/10.1016/j.apenergy.2013.10.047

Bokaie, M., Zarkesh, M. K., Arasteh, P. D., \& Hosseini, A. (2016). Assessment of Urban Heat Island based on the relationship 
between land surface temperature and Land Use/Land Cover in Tehran. Sustainable Cities and Society, 23, 94-104. https://doi.org/10.1016/j.scs.2016.03.009

Bowler, D. E., Buyung-Ali, L., Knight, T. M., \& Pullin, A. S. (2010). Urban greening to cool towns and cities: A systematic review of the empirical evidence. Landscape and Urban Planning, 97(3), 147-155.

https://doi.org/10.1016/j.landurbplan.2010.05.006

Burn, R. (1984). The fractal geometry of nature by Benoit B. Mandelbrot. The Mathematical Gazette, 68(443), 71-72. https://doi.org/10.2307/3615422

Carlson, T. N., \& Ripley, D. A. (1997). On the relation between NDVI, fractional vegetation cover, and leaf area index. Remote Sensing of Environment, 62(3), 241-252. https://doi.org/10.1016/S0034-4257(97)00104-1

Ceplova, N., Kalusova, V., \& Lososova, Z. (2017). Effects of settlement size, urban heat island and habitat type on urban plant biodiversity. Landscape and Urban Planning, 159, 15-22. https://doi.org/10.1016/j.landurbplan.2016.11.004

Chander, G., Markham, B. L., \& Helder, D. L. (2009). Summary of current radiometric calibration coefficients for Landsat MSS, TM, ETM+, and EO-1 ALI sensors. Remote Sensing of Environment, 113(5), 893-903.

https://doi.org/10.1016/j.rse.2009.01.007

Chen, Y., \& Yu, S. (2017). Impacts of urban landscape patterns on urban thermal variations in Guangzhou, China. International Journal of Applied Earth Observation and Geoinformation, 54, 65-71. https://doi.org/10.1016/j.jag.2016.09.007

Chian, S. C., \& Wilkinson, S. M. (2015). Feasibility of remote sensing for multihazard analysis of landslides in Padang Pariaman during the 2009 Padang Earthquake. Natural Hazards Review, 16(1). https://doi.org/10.1061/(ASCE)NH.1527-6996.0000143

Chui, A. C., Gittelson, A., Sebastian, E., Stamler, N., \& Gaffin, S. R. (2018). Urban heat islands and cooler infrastructure - Measuring near-surface temperatures with hand-held infrared cameras. Urban Climate, 24, 51-62. https://doi.org/10.1016/j.uclim.2017.12.009

Congalton, R. G. (1991). A review of assessing the accuracy of classifications of remotely sensed data. Remote Sensing of Environment, 37(1), 35-46.

https://doi.org/10.1016/0034-4257(91)90048-B

Czapla-Myers, J., McCorkel, J., Anderson, N., Thome, K., Biggar, S., Helder, D., Aaron, D., Leigh, L., \& Mishra, N. (2015). The ground-based absolute radiometric calibration of Landsat 8 OLI. Remote Sensing, 7(1), 600-626. https://doi.org/10.3390/rs70100600

Danila, E., Valentin, H., Georgescu, P. L., \& Moraru, L. (2019). Survey of forest cover changes by means of multifractal analysis. Carpathian Journal of Earth and Environmental Sciences, 14(1), 51-60. https://doi.org/10.26471/cjees/2019/014/057

Demuzere, M., Orru, K., Heidrich, O., Olazabal, E., Geneletti, D., Orru, H., Bhave, A. G., Mittal, N., Feliu, E., \& Faehnle, M. (2014). Mitigating and adapting to climate change: Multifunctional and multi-scale assessment of green urban infrastructure. Journal of Environmental Management, 146, 107115. https://doi.org/10.1016/j.jenvman.2014.07.025

Doick, K. J., Peace, A., \& Hutchings, T. R. (2014). The role of one large greenspace in mitigating London's nocturnal urban heat island. Science of the Total Environment, 493, 662-671. https://doi.org/10.1016/j.scitotenv.2014.06.048

Du, H., Cai, W., Xu, Y., Wang, Z., Wang, Y., \& Cai, Y. (2017). Quantifying the cool island effects of urban green spaces using remote sensing Data. Urban Forestry \& Urban Greening,
27, 24-31. https://doi.org/10.1016/j.ufug.2017.06.008

Duncan, J. M. A., Boruff, B., Saunders, A., Sun, Q., Hurley, J., \& Amati, M. (2019). Turning down the heat: An enhanced understanding of the relationship between urban vegetation and surface temperature at the city scale. Science of the Total Environment, 656, 118-128.

https://doi.org/10.1016/j.scitotenv.2018.11.223

Equere, V., Mirzaei, P. A., Riffat, S., \& Wang, Y. (2021). Integration of topological aspect of city terrains to predict the spatial distribution of urban heat island using GIS and ANN. Sustainable Cities and Society, 69, 102825.

https://doi.org/10.1016/j.scs.2021.102825

Esau, I., Miles, V., Varentsov, M., Konstantinov, P., \& Melnikov, V. (2019). Spatial structure and temporal variability of a surface urban heat island in cold continental climate. Theoretical and Applied Climatology, 137(3-4), 2513-2528. https://doi.org/10.1007/s00704-018-02754-Z

Estes, J. A., Heithaus, M., McCauley, D. J., Rasher, D. B., \& Worm, B. (2016). Megafaunal impacts on structure and function of ocean ecosystems. Annual Review of Environment and Resources, 41(1), 83-116.

https://doi.org/10.1146/annurev-environ-110615-085622

Fan, C., Myint, S. W., \& Zheng, B. (2015). Measuring the spatial arrangement of urban vegetation and its impacts on seasonal surface temperatures. Progress in Physical Geography-Earth and Environment, 39(2), 199-219.

https://doi.org/10.1177/0309133314567583

Fan, H., Yu, Z., Yang, G., Liu, T. Y., Liu, T. Y., Hung, C. H., \& Vejre, H. (2019). How to cool hot-humid (Asian) cities with urban trees? An optimal landscape size perspective. Agricultural and Forest Meteorology, 265, 338-348.

https://doi.org/10.1016/j.agrformet.2018.11.027

Fu, Y., Ren, Z., Yu, Q., He, X., Xiao, L., Wang, Q., \& Liu, C. (2019). Long-term dynamics of urban thermal comfort in China's four major capital cities across different climate zones. Peer J, 7, e8026. https://doi.org/10.7717/peerj.8026

Geletič, J., Lehnert, M., Savić, S., \& Milošević, D. (2019). Inter-/ intra-zonal seasonal variability of the surface urban heat island based on local climate zones in three central European cities. Building and Environment, 156, 21-32. https://doi.org/10.1016/j.buildenv.2019.04.011

Gong, W., Wang, H., Wang, X., Fan, W., \& Stott, P. (2017). Effect of terrain on landscape patterns and ecological effects by a gradient-based RS and GIS analysis. Journal of Forestry Research, 28(5), 1061-1072. https://doi.org/10.1007/s11676-017-0385-8

Guo, L., Liu, R., Men, C., Wang, Q., Miao, Y., \& Zhang, Y. (2019). Quantifying and simulating landscape composition and pattern impacts on land surface temperature: A decadal study of the rapidly urbanizing city of Beijing, China. Science of the Total Environment, 654, 430-440.

https://doi.org/10.1016/j.scitotenv.2018.11.108

Hamada, S., \& Ohta, T. (2010). Seasonal variations in the cooling effect of urban green areas on surrounding urban areas. Urban Forestry \& Urban Greening, 9(1), 15-24. https://doi.org/10.1016/j.ufug.2009.10.002

Hernandez-Moreno, A., \& Reyes-Paecke, S. (2018). The effects of urban expansion on green infrastructure along an extended latitudinal gradient (23 degrees S-45 degrees S) in Chile over the last thirty years. Land Use Policy, 79, 725-733. https://doi.org/10.1016/j.landusepol.2018.09.008

Imran, H. M., Kala, J., Ng, A. W. M., \& Muthukumaran, S. (2019). Effectiveness of vegetated patches as Green Infrastructure in mitigating Urban Heat Island effects during a heatwave event 
in the city of Melbourne. Weather and Climate Extremes, 25, 100217. https://doi.org/10.1016/j.wace.2019.100217

Jia, Q. (2009). Study of urban green patch's thermal environment effect with remote sensing: A case study of Chengdu City. Chinese Landscape Architecture.

Jiao, L., Xu, G., Jin, J., Dong, T., Liu, J., Wu, Y., \& Zhang, B. (2017). Remotely sensed urban environmental indices and their economic implications. Habitat International, 67, 22-32. https://doi.org/10.1016/j.habitatint.2017.06.012

John, V., Jain, P., Rahate, M., \& Labhasetwar, P. (2014). Assessment of deterioration in water quality from source to household storage in semi-urban settings of developing countries. Environmental Monitoring and Assessment, 186(2), 725-734. https://doi.org/10.1007/s10661-013-3412-z

Julien, Y., \& Sobrino, J. A. (2010). Comparison of cloud-reconstruction methods for time series of composite NDVI data. Remote Sensing of Environment, 114(3), 618-625. https://doi.org/10.1016/j.rse.2009.11.001

Kim, J.-H., Gu, D., Sohn, W., Kil, S.-H., Kim, H., \& Lee, D.-K. (2016). Neighborhood landscape spatial patterns and land surface temperature: An empirical study on single-family residential areas in Austin, Texas. International Journal of Environmental Research and Public Health, 13(9), 880. https://doi.org/10.3390/ijerph13090880

Koc, C. B., Osmond, P., \& Peters, A. (2017). Towards a comprehensive green infrastructure typology: A systematic review of approaches, methods and typologies. Urban Ecosystems, 20(1), 15-35. https://doi.org/10.1007/s11252-016-0578-5

Kong, F., Yin, H., James, P., Hutyra, L. R., \& He, H. S. (2014a). Effects of spatial pattern of greenspace on urban cooling in a large metropolitan area of eastern China. Landscape and Urban Planning, 128, 35-47. https://doi.org/10.1016/j.landurbplan.2014.04.018

Kong, F., Yin, H., Wang, C., Cavan, G., \& James, P. (2014b). A satellite image-based analysis of factors contributing to the green-space cool island intensity on a city scale. Urban Forestry \& Urban Greening, 13(4), 846-853. https://doi.org/10.1016/j.ufug.2014.09.009

Li, C., Zhao, J., Nguyen Xuan, T., Yang, W., \& Li, Z. (2018). Analysis of the spatiotemporally varying effects of urban spatial patterns on land surface temperatures. Journal of Environmental Engineering and Landscape Management, 26(3), 216-231. https://doi.org/10.3846/jeelm.2018.5378

Li, Y., \& Zhao, X. (2012). An empirical study of the impact of human activity on long-term temperature change in China: A perspective from energy consumption. Journal of Geophysical Research - Atmospheres, 117(D17), 1-12. https://doi.org/10.1029/2012JD018132

Li, Y., Sun, Y., Li, J., \& Gao, C. (2020). Socioeconomic drivers of urban heat island effect: Empirical evidence from major Chinese cities. Sustainable Cities and Society, 63, 102425. https://doi.org/10.1016/j.scs.2020.102425

Liu, Y., Peng, J., \& Wang, Y. (2017). Diversification of land surface temperature change under urban landscape renewal: A case study in the main city of Shenzhen, China. Remote Sensing, 9(9), 919. https://doi.org/10.3390/rs9090919

Maimaitiyiming, M., Ghulam, A., Tiyip, T., Pla, F., Latorre-Carmona, P., Halik, U., Sawut, M., \& Caetano, M. (2014). Effects of green space spatial pattern on land surface temperature: Implications for sustainable urban planning and climate change adaptation. ISPRS Journal of Photogrammetry and Remote Sensing, 89, 59-66.

https://doi.org/10.1016/j.isprsjprs.2013.12.010

Mallen, E., Stone, B., \& Lanza, K. (2019). A methodological assessment of extreme heat mortality modeling and heat vulnerability mapping in Dallas, Texas. Urban Climate, 30, 100528. https://doi.org/10.1016/j.uclim.2019.100528

Manoli, G., Fatichi, S., Schlapfer, M., Yu, K., Crowther, T. W., Meili, N., Burlando, P., Katul, G. G., \& Bou-Zeid, E. (2019). Magnitude of urban heat islands largely explained by climate and population. Nature, 573, 55-60.

https://doi.org/10.1038/s41586-019-1512-9

Masek, J. G., Vermote, E. F., Saleous, N. E., Wolfe, R., Hall, F. G., Huemmrich, K. F., Feng, G., Kutler, J., \& Teng-Kui, L. (2006). A Landsat surface reflectance dataset for North America, 1990-2000. IEEE Geoscience and Remote Sensing Letters, 3(1), 68-72. https://doi.org/10.1109/LGRS.2005.857030

Masoudi, M., \& Tan, P. Y. (2019). Multi-year comparison of the effects of spatial pattern of urban green spaces on urban land surface temperature. Landscape and Urban Planning, 184, 44-58. https://doi.org/10.1016/j.landurbplan.2018.10.023

McGarigal, K. S., Cushman, S., Neel, M., \& Ene, E. (2002). FRAGSTATS: Spatial pattern analysis program for categorical maps. https://www.researchgate.net/publication/259011515_ FRAGSTATS_Spatial_pattern_analysis_program_for_categorical_maps

Meng, Y., Liu, X., Wu, L., Liu, M., Zhang, B., \& Zhao, S. (2019). Spatio-temporal variation indicators for landscape structure dynamics monitoring using dense normalized difference vegetation index time series. Ecological Indicators, 107, 105607. https://doi.org/10.1016/j.ecolind.2019.105607

Monteiro, M. V., Doick, K. J., Handley, P., \& Peace, A. (2016). The impact of greenspace size on the extent of local nocturnal air temperature cooling in London. Urban Forestry \& Urban Greening, 16, 160-169. https://doi.org/10.1016/j.ufug.2016.02.008

Myint, S. W., Zheng, B., Talen, E., Fan, C., Kaplan, S., Middel, A., Smith, M., Huang, H.-p., \& Brazel, A. (2015). Does the spatial arrangement of urban landscape matter? Examples of urban warming and cooling in Phoenix and Las Vegas. Ecosystem Health and Sustainability, 1(4), 1-15. https://doi.org/10.1890/EHS14-0028.1

Naeem, S., Cao, C., Qazi, W. A., Zamani, M., Wei, C., Acharya, B. K., \& Rehman, A. U. (2018). Studying the association between green space characteristics and land surface temperature for sustainable urban environments: An analysis of Beijing and Islamabad. ISPRS International Journal of GeoInformation, 7(2), 38. https://doi.org/10.3390/ijgi7020038

Ngulani, T., \& Shackleton, C. M. (2020). The degree, extent and value of air temperature amelioration by urban green spaces in Bulawayo, Zimbabwe. South African Geographical Journal, 102(3), 344-355.

https://doi.org/10.1080/03736245.2019.1685405

Noori, A. M., Pradhan, B., \& Ajaj, Q. M. (2019). Dam site suitability assessment at the Greater Zab River in northern Iraq using remote sensing data and GIS. Journal of Hydrology, 574, 964-979. https://doi.org/10.1016/j.jhydrol.2019.05.001

Novikmec, M., Svitok, M., Kocicky, D., Sporka, F., \& Bitusik, P. (2013). Surface water temperature and ice cover of Tatra Mountains Lakes depend on altitude, topographic shading, and bathymetry. Arctic Antarctic and Alpine Research, 45(1), 77-87. https://doi.org/10.1657/1938-4246-45.1.77

Ode, A., Hagerhall, C. M., \& Sang, N. (2010). Analysing Visual Landscape Complexity: Theory and Application. Landscape Research, 35(1), 111-131.

https://doi.org/10.1080/01426390903414935

Ogashawara, I., \& Brum Bastos, V. d. S. (2012). A quantitative approach for analyzing the relationship between urban heat 
islands and land cover. Remote Sensing, 4(11), 3596-3618. https://doi.org/10.3390/rs4113596

Oliveira, S., Andrade, H., \& Vaz, T. (2011). The cooling effect of green spaces as a contribution to the mitigation of urban heat: A case study in Lisbon. Building and Environment, 46(11), 2186-2194. https://doi.org/10.1016/j.buildenv.2011.04.034

Papadimitriou, F. (2010). Conceptual modelling of landscape complexity. Landscape Research, 35(5), 563-570. https://doi.org/10.1080/01426397.2010.504913

Peng, J., Jia, J., Liu, Y., Li, H., \& Wu, J. (2018). Seasonal contrast of the dominant factors for spatial distribution of land surface temperature in urban areas. Remote Sensing of Environment, 215, 255-267. https://doi.org/10.1016/j.rse.2018.06.010

Peng, J., Xie, P., Liu, Y., \& Ma, J. (2016). Urban thermal environment dynamics and associated landscape pattern factors: A case study in the Beijing metropolitan region. Remote Sensing of Environment, 173, 145-155. https://doi.org/10.1016/j.rse.2015.11.027

Peng, X., Wu, W., Zheng, Y., Sun, J., Hu, T., \& Wang, P. (2020). Correlation analysis of land surface temperature and topographic elements in Hangzhou, China. Scientific Reports, 10(1), 10451. https://doi.org/10.1038/s41598-020-67423-6

Rahman, M. A., Armson, D., \& Ennos, A. R. (2015). A comparison of the growth and cooling effectiveness of five commonly planted urban tree species. Urban Ecosystems, 18(2), 371-389. https://doi.org/10.1007/s11252-014-0407-7

Rahman, M. A., Moser, A., Roetzer, T., \& Pauleit, S. (2017). Microclimatic differences and their influence on transpirational cooling of Tilia cordata in two contrasting street canyons in Munich, Germany. Agricultural and Forest Meteorology, 232, 443-456. https://doi.org/10.1016/j.agrformet.2016.10.006

Rasul, A., Balzter, H., \& Smith, C. (2015). Spatial variation of the daytime Surface Urban Cool Island during the dry season in Erbil, Iraqi Kurdistan, from Landsat 8. Urban Climate, 14(Part 2), 176-186.

https://doi.org/10.1016/j.uclim.2015.09.001

Romme, W. H. (1982). Fire and landscape diversity in Subalpine Forests of Yellowstone National Park. Ecological Monographs, 52(2), 199-221. https://doi.org/10.2307/1942611

Rouse, D. C., \& Bunster-Ossa, I. F. (2013). Green infrastructure: A landscape approach. https://caeau.com.ar/wp-content/uploads/2018/11/46.GREEN-INFRAESTRUCTURE.pdf

Rubiano, K. (2019). Distribución de la infraestructura verde y su capacidad de regulación térmica en Bogotá, Colombia [Distribution of the green infrastructure and its thermal regulation capacity in Bogotá, Colombia]. Colombia Forestal, 22(2), 83-100. https://doi.org/10.14483/2256201X.14304

Santamouris, M., Cartalis, C., Synnefa, A., \& Kolokotsa, D. (2015). On the impact of urban heat island and global warming on the power demand and electricity consumption of buildings - A review. Energy and Buildings, 98, 119-124. https://doi.org/10.1016/j.enbuild.2014.09.052

Shi, D., Song, J., Huang, J., Zhuang, C., Guo, R., \& Gao, Y. (2020). Synergistic cooling effects (SCEs) of urban green-blue spaces on local thermal environment: A case study in Chongqing, China. Sustainable Cities and Society, 55, 102065. https://doi.org/10.1016/j.scs.2020.102065

Shishegar, N. (2015). The impact of green areas on mitigating urban heat island effect: A review. The International Journal of Environmental Sustainability, 9(1), 119-130.

https://doi.org/10.18848/2325-1077/CGP/v09i01/55081

Simpson, E. H. (1949). Measurement of diversity. Nature, 163, 688. https://doi.org/10.1038/163688a0

Sobrino, J. A., Jiménez-Muñoz, J. C., \& Paolini, L. (2004). Land surface temperature retrieval from LANDSAT TM 5. Remote Sensing of Environment, 90(4), 434-440.

https://doi.org/10.1016/j.rse.2004.02.003

Solecki, W. D., Rosenzweig, C., Parshall, L., Pope, G., Clark, M., Cox, J., \& Wiencke, M. (2005). Mitigation of the heat island effect in urban New Jersey. Global Environmental Change Part B: Environmental Hazards, 6(1), 39-49.

https://doi.org/10.1016/j.hazards.2004.12.002

Sookhan, N., Margolis, L., \& MacIvor, J. S. (2018). Inter-annual thermoregulation of extensive green roofs in warm and cool seasons: Plant selection matters. Ecological Engineering, 123, 10-18. https://doi.org/10.1016/j.ecoleng.2018.08.016

Sun, R., Xie, W., \& Chen, L. (2018). A landscape connectivity model to quantify contributions of heat sources and sinks in urban regions. Landscape and Urban Planning, 178, 43-50. https://doi.org/10.1016/j.landurbplan.2018.05.015

Sun, R., \& Chen, L. (2012). How can urban water bodies be designed for climate adaptation? Landscape and Urban Planning, 105(1-2), 27-33.

https://doi.org/10.1016/j.landurbplan.2011.11.018

Timm, B. C., \& McGarigal, K. (2012). Fine-scale remotely-sensed cover mapping of coastal dune and salt marsh ecosystems at Cape Cod National Seashore using Random Forests. Remote Sensing of Environment, 127, 106-117. https://doi.org/10.1016/j.rse.2012.08.033

United Nations. (2014, July 10). World's population increasingly urban with more than half living in urban areas.

https://www.un.org/en/development/desa/news/population/ world-urbanization-prospects-2014.html

Venter, Z. S., Krog, N. H., \& Barton, D. N. (2020). Linking green infrastructure to urban heat and human health risk mitigation in Oslo, Norway. Science of the Total Environment, 709, 136193. https://doi.org/10.1016/j.scitotenv.2019.136193

Voogt, J. A., \& Oke, T. R. (2003). Thermal remote sensing of urban climates. Remote Sensing of Environment, 86(3), 370-384. https://doi.org/10.1016/S0034-4257(03)00079-8

Wang, D., Lau, K. K.-L., Ren, C., Goggins, W. B. I. I. I., Shi, Y., Ho, H. C., Lee, T.-C., Lee, L.-S., Woo, J., \& Ng, E. (2019a). The impact of extremely hot weather events on all-cause mortality in a highly urbanized and densely populated subtropical city: A 10-year time-series study (2006-2015). Science of the Total Environment, 690, 923-931.

https://doi.org/10.1016/j.scitotenv.2019.07.039

Wang, Y.-C., Shen, J.-K., \& Xiang, W.-N. (2018). Ecosystem service of green infrastructure for adaptation to urban growth: Function and configuration. Ecosystem Health and Sustainability, 4(5), 132-143. https://doi.org/10.1080/20964129.2018.1474721

Wang, Y., Shen, J., Yan, W., \& Chen, C. (2019b). Effects of landscape development intensity on river water quality in urbanized areas. Sustainability, 11(24), 7120. https://doi. org/10.3390/su11247120

Weng, Q., Liu, H., Liang, B., \& Lu, D. (2008). The spatial variations of urban land surface temperatures: pertinent factors, zoning effect, and seasonal variability. IEEE Journal of Selected Topics in Applied Earth Observations and Remote Sensing, 1(2), 154-166. https://doi.org/10.1109/JSTARS.2008.917869

Weng, Q., Liu, H., \& Lu, D. (2007). Assessing the effects of land use and land cover patterns on thermal conditions using landscape metrics in city of Indianapolis, United States. Urban Ecosystems, 10(2), 203-219.

https://doi.org/10.1007/s11252-007-0020-0

Wu, C., Li, J., Wang, C., Song, C., Chen, Y., Finka, M., \& La Rosa, D. (2019). Understanding the relationship between 
urban blue infrastructure and land surface temperature. Science of the Total Environment, 694, 133742.

https://doi.org/10.1016/j.scitotenv.2019.133742

Wu, J., Li, C., Zhang, X., Zhao, Y., Liang, J., \& Wang, Z. (2020). Seasonal variations and main influencing factors of the water cooling islands effect in Shenzhen. Ecological Indicators, 117, 106699. https://doi.org/10.1016/j.ecolind.2020.106699

Wu, J., Gao, W., \& Tueller, P. T. (1997). Effects of changing spatial scale on the results of statistical analysis with landscape data: A case study. Geographic Information Sciences, 3(1-2), 30-41. https://doi.org/10.1080/10824009709480491

Yang, C., He, X., Wang, R., Yan, F., Yu, L., Bu, K., Yang, J., Chang, L., \& Zhang, S. (2017). The effect of urban green spaces on the urban thermal environment and its seasonal variations. Forests, 8(5), 153. https://doi.org/10.3390/f8050153

Yang, G., Yu, Z., Jorgensen, G., \& Vejre, H. (2020). How can urban blue-green space be planned for climate adaption in highlatitude cities? A seasonal perspective. Sustainable Cities and Society, 53, 101932. https://doi.org/10.1016/j.scs.2019.101932

Yu, Z., Guo, X., Jorgensen, G., \& Vejre, H. (2017). How can urban green spaces be planned for climate adaptation in subtropical cities? Ecological Indicators, 82, 152-162. https://doi.org/10.1016/j.ecolind.2017.07.002

Zhang, C., Yue, Q., \& Guo, P. (2019). A nonlinear inexact twostage management model for agricultural water allocation under uncertainty based on the Heihe River water diversion plan. International Journal of Environmental Research and Public Health, 16(11), 1884. https://doi.org/10.3390/ijerph16111884

Zhang, X. M., Estoque, R. C., \& Murayama, Y. (2017a). An urban heat island study in Nanchang City, China based on land surface temperature and social-ecological variables. Sustainable Cities and Society, 32, 557-568. https://doi.org/10.1016/j.scs.2017.05.005
Zhang, X. P., Wang, D., Hao, H., Zhang, F., \& Hu, Y. (2017b). Effects of land use/cover changes and urban forest configuration on urban heat islands in a Loess Hilly Region: Case study based on Yan'an City, China. International Journal of Environmental Research and Public Health, 14(8), 840. https://doi.org/10.3390/ijerph14080840

Zhang, Y., Zhan, Y., Yu, T., \& Ren, X. (2017c). Urban green effects on land surface temperature caused by surface characteristics: A case study of summer Beijing metropolitan region. Infrared Physics \& Technology, 86, 35-43. https://doi.org/10.1016/j.infrared.2017.08.008

Zhao, N., Jiao, Y., Ma, T., Zhao, M., Fan, Z., Yin, X., Liu, Y., \& Yue, T. (2019). Estimating the effect of urbanization on extreme climate events in the Beijing-Tianjin-Hebei region, China. Science of the Total Environment, 688, 1005-1015. https://doi.org/10.1016/j.scitotenv.2019.06.374

Zhao, W., Yan, T., Ding, X., Peng, S., Chen, H., Fu, Y., \& Zhou, Z. (2021). Response of ecological quality to the evolution of land use structure in Taiyuan during 2003 to 2018. Alexandria Engineering Journal, 60(1), 1777-1785. https://doi.org/10.1016/j.aej.2020.11.026

Zhou, D., Xiao, J., Bonafoni, S., Berger, C., Deilami, K., Zhou, Y., Frolking, S., Yao, R., Qiao, Z., \& Sobrino, J. A. (2019a). Satellite remote sensing of surface urban heat islands: Progress, challenges, and perspectives. Remote Sensing, 11(1), 48. https://doi.org/10.3390/rs11010048

Zhou, W., Cao, F., \& Wang, G. (2019b). Effects of spatial pattern of forest vegetation on urban cooling in a compact megacity. Forests, 10(3), 282. https://doi.org/10.3390/f10030282

Zhou, W., Huang, G., \& Cadenasso, M. L. (2011). Does spatial configuration matter? Understanding the effects of land cover pattern on land surface temperature in urban landscapes. Landscape and Urban Planning, 102(1), 54-63. https://doi.org/10.1016/j.landurbplan.2011.03.009 